\title{
The Eo-Cimmerian orogeny in North Iran
}

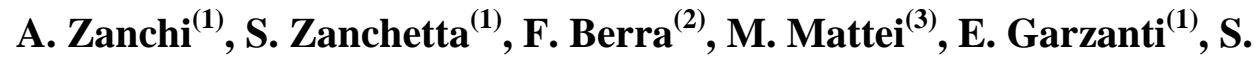
Molyneux $^{(4)}$, A. Nawab ${ }^{(5)}$, J. Sabouri ${ }^{(5)}$

(1) Dipartimento Scienze Geologiche e Geotecnologie, Università di Milano-Bicocca, Piazza della Scienza 4, Milano, 20126 Italy; andrea.zanchi@unimib.it

(2) Dipartimento di Scienze della Terra, Università di Milano, Via Mangiagalli 34, 20133

Milano, Italy

(3) Dipartimento di Scienze Geologiche, Largo San Leonardo Murialdo 1, 00146 Roma-I,

Università Roma TRE,

(4) British Geological Survey, Kingsley Dunham Centre, Keyworth, Nottingham, NG12 5GG, United Kingdom

(5) Geological Survey of Iran, Azadi Square, Meraj Ave., 13185-1494, Tehran, Iran number of words of text: 7120, references 1751, tables 560 and figures 1378

\section{Abbreviated title: The Eo-Cimmerian orogeny in North Iran}

Keywords: Iran, Cimmerian orogeny, structural geology, eclogites, unconformity, Triassic.

Abstract: The Eo-Cimmerian orogen results from the Late Triassic collision of Iran, a microplate of Gondwanan affinity, with the southern margin of Eurasia. The orogen is discontinuously exposed along the northern side of the Alborz Mountains of North Iran, below the siliciclastic deposits of the Shemshak Formation (Late Triassic to Jurassic). A preserved section of the external part of the belt crops out in the Neka valley (eastern Alborz) south of Gorgan. Here the Mesozoic successions (Shemshak Formation to Upper Cretaceous limestones) overlie with a sharp unconformity a preJurassic Eo-Cimmerian thrust stack. The stack includes the Gorgan Schists, an Upper Ordovician-Lower Silurian LG-metamorphic complex, overthrust southward above a strongly deformed Late Palaeozoic to Middle Triassic succession belonging to North Iran. In the Talesh Mountains (western Alborz), the Shanderman Complex, 
interpreted as an ophiolitic remnant, is an allochthonous nappe of deeply subducted continental crust, as testified by the occurrence of previously unknown eclogites dating to the Carboniferous, and probably related to the Variscan history of Transcaucasia. South of the Shanderman Complex, Upper Palaeozoic slates and carbonates occurring below the Lower Jurassic Shemshak Formation also record the occurrence of an Eo-Cimmerian metamorphic event. Based on our new data, we interpret the Eo-Cimmerian structures exposed in the Alborz as the remnants of a collisional orogen mainly consisting of deformed continental crust where no ophiolites are preserved.

\section{Introduction}

The early Mesozoic Cimmerian orogeny, which produced the final closure of the Palaeotethys Ocean and the accretion of Gondwana-derived microplates to southern Eurasia, was firstly recognized in Iran (Stocklin 1974). This event, which reshaped the eastern Eurasian margin from Timor to Turkey between the Triassic and the Jurassic, still presents unclear aspects concerning the location, extent, timing and evolution of the Eo-Cimmerian orogen. Since Stocklin (1974), the continental blocks forming North and Central Iran (Fig.1) have been considered to be of Gondwanan affinity for several reasons: a) their pre-Palaeozoic basement is thought to be related to the "Pan-African" orogeny; b) Precambrian-Cambrian sedimentary rocks are continuous across the Zagros suture. The region lacks a Variscan deformation (Saidi et al. 1997), whereas its northern portion, now occupied by the Alborz belt, was involved in the Cimmerian orogeny (Sengor 1990).

According to most authors, Iran drifted northward since Early Permian times as part of the Cimmerian blocks (Sengor 1979, 1984, 1990; Angiolini et al. 2007) or MegaLhasa (Dercourt et al. 2000) following the opening of Neotethys. Collision with Eurasia s.l. occurred during the Late Triassic, resulting in the Eo-Cimmerian deformation in North Iran, followed by a strong but poorly known Neo-Cimmerian compressional event during Middle-Late Jurassic times that mainly affected Central Iran. Available paleomagnetic data (Besse et al. 1998; Wensink et al. 1978; Muttoni et al., this vol.) also suggest that at least some portions of Central Iran (e.g. Abadeh) and the Alborz area moved in conjunction from southern latitudes in the Early 
Permian to northern latitudes in the Early-Middle Triassic, crossing subequatorial latitudes in Middle-Late Permian times.

Most authors agree on the occurrence of a major northward dipping subduction zone below the Eurasian margin during Permo- Triassic times, now located at the latitude of the southern Caspian coast (Berberian \& King 1981; Alavi 1991, 1997; Boulin 1991; Ruttner 1993). Remnants of one major Palaeotethys suture between Eurasia s.l. and the Iranian block were firstly recognized in NE Iran around Mashad and eastward, where thin slices of ultramafic rocks associated with pillow lavas, phyllites, and siliciclastic turbidites were interpreted as an accretionary wedge formed during Permo-Triassic times (Alavi 1991; Ruttner 1993). The flatlying Middle Jurassic Kashaf Rud Formation, post-dating the final accretion of Iran to the southern margin of Eurasia, definitively seals the collision zone, although undated conglomerates and sandstones (Geological Survey of Iran 1986, 1996; Alavi 1991) exposed below the Kashaf Rud Formation around Mashad might constrain the time of deformation to the end of the Triassic or the beginning of the Jurassic.

The continuation of the suture zone to the west, proposed by Alavi (1996), across central and western Alborz (Talesh Mountains) is questionable. According to most authors, docking of the Iranian block to Eurasia occurred in the Late Triassic times. The collision is marked by an angular unconformity between the Upper Precambrian to Middle Triassic successions of North Iran and the Norian to Lower Jurassic Shemshak Formation, a thick terrigenous clastic unit generally considered to be the “Cimmerian molasse” (Seyed-Emami 2003; Fursich et al. 2005).

In this paper, we present a first systematic description of the tectonic setting of the Alborz region during the Eo-Cimmerian event. This reconstruction is based on new data collected in the Alborz belt in the region south of Gorgan and in the Talesh Mountains (Fig. 1). The integration of structural, stratigraphical and petrological data allows us to envisage a new tectonic scenario for the Eo-Cimmerian orogeny in North Iran.

\section{Geological setting of the Alborz}

The Alborz belt is a $1500 \mathrm{~km}$ long mountain system extending from Azerbaijan to Afghanistan, flanking in its central part the southern coast of the Caspian Sea (Fig. 2). The belt was affected by several successive tectonic events, from the Eo-Cimmerian 
orogeny to Late Tertiary-Quaternary intracontinental transpression (Allen et al. 2003a), and is still strongly seismically active (Ritz et al. 2006). Important compressional events also occurred at the end of the Cretaceous (Guest et al. 2006a), related to retro-arc compression induced by the subduction of the Neotethys below the Sanandaj-Sirjan zone and by the subduction of the Nain-Baft ocean directly below Central Iran (Ghasemi \& Talbot 2006). Extensive mapping by the Geological Survey of Iran (Geological Survey of Iran, 1977, 1985, 1987, 1988, 1991a, 1991b, 1991c, 1997, 2001, 2004) and recent studies now provide an accurate stratigraphical and structural general framework of the belt (Alavi 1996; Allen et al. 2003a, 2003b; Guest et al., 2006a, 2006b; Zanchi et al. 2006).

\subsection{Stratigraphic framework}

The stratigraphic successions preserved in the Alborz (Assereto 1966b; Alavi 1991) are overall more than $12 \mathrm{~km}$ thick, ranging from the latest Precambrian to the Holocene. The uppermost Precambrian to Middle Triassic sedimentary successions were deposited along a passive margin affected by the opening of the Palaeotethys Ocean during Early Palaeozoic times and by the opening of the Neotethys Ocean in the Late Palaeozoic (Stampfli et al. 1991). No Precambrian crystalline basement crops out in the belt, with the exception of the Lahijan Granite east of Rasht, which has given a late Neoproterozoic to Cambrian U-Pb zircon crystallization age (Guest et al. 2006b). The terrigenous Shemshak Formation overlies with angular unconformity the aforementioned successions deformed during the Middle-Late Triassic EoCimmerian orogenesis.

About 3000 m of Precambrian and Cambrian shallow-marine sandstone and dolostone, with Lower Cambrian continental deposits, form the base of the succession. Lower to Middle Ordovician glauconitic shale and siltstone follow. Ordovician and Silurian strata are largely lacking in the central Alborz, whereas a thick succession of volcanic deposits including lava flows, intercalated with Orthoceras-bearing limestones, occurs in the Talesh Mountains (western Alborz) and east of Gorgan, where basaltic to andesitic lava flows are associated with ignimbrites and intrusive rocks including syenite, diorite and gabbro (Davies et al. 1972; Geological Survey of Iran 1991b 1997). Thick lava flows are widespread also at the base of the Devonian units. Wendt et al. (2005), observing the strong difference of 
the Palaeozoic successions of the Talesh Mountains, suggested the possibility that they represented the distal portion of the Iranian Plate or alternatively that they belonged to the Turan Plate. The entire volcanic succession was interpreted as representative of an important rifting event (Berberian \& King 1981; Stampfli et al. 1991).

The Devonian to Middle Triassic succession is $1300-1500 \mathrm{~m}$ thick and includes shallow marine ramp carbonates, evolving to carbonate platforms in the Triassic (Elika Formation). Intercalated siliciclastic units (Qezel Qaleh Formation) and unconformities occur within the Carboniferous carbonates (Mobarak Formation), at the base of the Permian units (Dorud Formation) and, in eastern Alborz, between the Ruteh and Elika Formations. They mark several uplift episodes, possibly related to the effects of faraway tectonic events (Gaetani et al., this volume).

The whole pre-Middle Triassic succession is sealed with angular unconformity by the Upper Triassic-Middle Jurassic sediments of the Shemshak Formation, locally reaching $4000 \mathrm{~m}$ in thickness. The base of the formation is markedly heterochronous, ranging from Carnian in central Alborz to Toarcian close to the Caspian coast (Clark et al. 1975; Seyed-Emami 2003, Ghasemi-Nejad et al. 2004; Fursich et al. 2005). This unit includes deltaic to shallow-marine sandstone, conglomerate, shale and coal layers that seal the Eo-Cimmerian orogen and its foreland. The "Cimmerian unconformity" is subtle, commonly passing to a paraconformity in the northern and axial part of the central Alborz, whereas in the Shemshak area the basal beds of the Shemshak Formation lie on Permian to Middle Triassic units. In the Talesh and Gorgan regions, west and east of the study region, the Shemshak Formation nonconformably seals the Eo-Cimmerian nappes. Thick basaltic lava flows commonly occur above the unconformity, especially in the southern Alborz.

Upper Jurassic to Cretaceous shallow-water limestones and marls, intercalated with uppermost Jurassic basaltic flows are locally preserved. In the Gorgan region, Upper Cretaceous limestones definitively seal the topographic Eo-Cimmerian relief, with spectacular angular unconformity (Berra et al. 2007). The Cretaceous limestones commonly show closed folds and thrust faults sealed by the Palaeocene Fajan conglomerates, marking a new important tectonic event in the belt. The Eocene volcanic and volcanoclastic rocks of the Karaj Formation, more than 3000 m thick in the type area, stratigraphycally follow the conglomerates. This unit, which is much 
thicker south of the Talesh Mountains, and progressively thins out eastward and northward, is related to the growth of an intracontinental volcanic arc in an extensional setting related to the last phases of the Neotethys subduction along the Zagros suture zone to the southwest (Alavi 1996). The Neogene successions show different facies and thickness, including continental deposits in the Talesh area and shallow marine, coastal, fine-grained terrigenous bodies with gypsum layers and bioclastic limestones in southern central Alborz. These basins possibly formed in a foreland basin developed at the front of the growing Alborz belt. Quaternary alluvial deposits form thick accumulations in front of the belt, especially south of Teheran and along the eastern part of the southern Caspian coast, where they are strongly deformed and uplifted by active faults (Astaneh/Firuzkuh/Mosha, N-Teheran/Qazvin faults to the south, Khazar and South Talesh faults to the north.

\subsection{Tectonic setting}

The Alborz belt can be divided into two main portions that show a different structural setting: western Alborz, forming the Talesh Mountains, and central-eastern Alborz east of Rasht. The separation between the two parts of the belt is at the longitude of Rasht, where lateral ramps and transverse faults occur along the Sefid Rud.

The Talesh Mountains are narrower than 50 km, whereas the central and eastern Alborz reach $100 \mathrm{~km}$. In the analysed part of the Talesh Mountains, a set of parallel SW-verging Late Neogene thrust faults form huge ramp anticlines uplifting the Palaeozoic succession in their hanging walls. N-S striking dextral strike-slip faults form the western lateral ramps of the main thrusts. A poorly exposed N-S fault associated with earthquakes related to thrusting along a horizontal fault plane (Jackson et al. 2002) marks the Eastern margin of the belt. The Talesh Mountains include a few isolated strips of metamorphic rocks, the Gasht and Shanderman complexes, exposed along the northern slopes of the belt along the South Caspian Coast. Recent thrusts and strike-slip faults, which obscure their original relationships with the surrounding Palaeo-Mesozoic successions, define the boundaries of the two units. The Shanderman Complex, cropping out just west of Rasht along the Caspian foothills of the Talesh Mountains, is described as a deformed association of slate, phyllite, gneiss and amphibolite with small patches of serpentinized peridotite affected by a medium-grade metamorphism (Davies et al. 1972; Clark et al. 1975). 
Based on presumed lithological similarities, Alavi $(1991,1996)$ suggested that the Shanderman Complex is an ophiolitic unit equivalent to the ones exposed near Mashad, tracing the Palaeotethys suture along the South Caspian Coast from there to the Talesh region.

The Gasht Complex consists of two units with a different metamorphic imprint. The lower succession mainly includes medium- to high-grade metapelite, quartzite and amphibolite intruded by granitoids later affected by a retrograde metamorphism. RbSr dating obtained on phyllite (Crawford 1977) gave a problematic Middle to Late Devonian age of $382 \pm 48 \mathrm{Ma}$ and $375 \pm 12 \mathrm{Ma}$. The upper unit includes slate, phyllite and quartzite. Clark et al. (1975) also described very low-grade metapelites with Upper Palaeozoic limestone intercalations around Masuleh and along the Shah Rud. The Shemshak Formation non-conformably covers the metamorphic units of the Talesh area. The lowermost marine beds of the formation date to the lower Lias, but its base could be older (Davies et al. 1972). Granitoids intruding these metamorphic units point to a Cimmerian age of emplacement (175 Ma; Crawford 1977). Centraleastern Alborz is dominated from west to east by WNW-ESE, E-W, and ENE-WSW trending high-angle and vertical faults running parallel to the belt (Fig.2). Right- and left-lateral strike-slip motions and oblique to dip-slip movements (Allen et al. 2003a, 2003b; Guest et al. 2006a; Zanchi et al. 2006) occur in the internal part of the belt, whereas reverse and thrust faults characterize the external fronts. The uppermost Precambrian to Lower Mesozoic units form the backbone of the present-day mountain chain between the Kojour fault to the north and the Kandevan Thrust to the south in central Alborz. The northern part of the central Alborz belt consists of poorly deformed, thick Mesozoic marine successions, delimited to the north by the active Khazar thrust running parallel to the Caspian Sea. In the Gorgan region a low-grade unit, the Gorgan Schists, forms the northernmost part of the belt. Although Alavi (1996) assigned a possible Palaeozoic to Triassic age to the Gorgan Schists, these rocks have been recently attributed to the Early Palaeozoic (Geological Survey of Iran 1997).

The main structures of the internal part of the eastern Alborz are the poorly studied North Alborz and Badaleh faults both trending ENE-WSW. The North Alborz Fault has been interpreted in different ways (Geological Survey of Iran 1991b, 1997; Allen et al. 2003a). According to recent maps, it is a high-angle north-dipping fault, which 
marks the boundary between the Palaeozoic to Middle Triassic successions to the north, deformed during the Eo- Cimmerian event, and its undeformed foreland to the south (Geological Survey of Iran 1997). The southern part of the belt shows a complex tectonic setting characterized by strong shortening, because of a complex interaction among strike-slip and reverse faults producing the uplift of the lower part of the Palaeozoic succession (Allen et al. 2003a; Guest et al. 2006a). The exposure of the Palaeozoic units in the Shemshak region of the central Alborz is believed to represent the effect of a mainly Cenozoic inversion of Middle to Late Triassic extensional structures formed in the foreland basin of the Eo-Cimmerian orogen (Zanchi et al. 2006).

Important dextral strike-slip ENE-WSW trending faults have been recognized by several authors (Axen et al. 2001; Allen et al. 2003a; Zanchi et al. 2006) and related to a N-S compression active during the Miocene. A recent change in the sense of shearing from dextral to sinistral along the main faults parallel to the belt has been related to the a major plate reorganization following the Eurasia-Arabia collision (Jackson et al. 2002), inducing a northwest-ward motion of the South Caspian since the Middle Pleistocene (Ritz et al. 2006). Oblique convergence along the centraleastern Alborz is now absorbed by major active transtensional faults as the AstanehFiruzkuh-Mosha fault system (Ritz et al. 2006), showing a left-lateral offset of about $30 \mathrm{~km}$ west of Teheran (Allen et al. 2003a).

\section{The Eo-Cimmerian structures in the Alborz}

\subsection{The Gorgan region}

Fieldwork was carried out around the town of Gorgan and along the Neka valley, where the Palaeo-Mesozoic successions of the Alborz are well exposed (Fig. 3, 4). Three main different tectonostratigraphic units have been analysed between the South Caspian coast and the North Alborz Fault: (1) the Gorgan Schists forming the strongly forested high mountain ridge (2400 m) running parallel to the Caspian coast; (2) the Palaeozoic to Triassic sedimentary succession of North Iran, which was deformed during the Eo-Cimmerian orogeny; (3) an ?Upper Triassic to Cretaceous sedimentary succession unconformably covering the two previous units (Fig. 5). 


\subsubsection{The Gorgan Schists}

The Gorgan Schists form the high topographic relief that borders the SE Caspian coast from the town of Neka to Aliabad. The active Gorgan (Khazar) thrust fault, which dips southward, bounds the Gorgan Schist to the north. The metamorphic complex is stacked southward on the Palaeozoic successions of North Iran along the Radekhan Fault, an Eo-Cimmerian high angle north-dipping fault crossing the northern flank of the Neka Valley (Fig. 4). The Gorgan Schists mainly consist of slate and phyllite including a thick volcanic to volcanoclastic succession, intruded by small basic and acidic bodies exposed south of Gorgan. Thin marble layers with fossil ghosts commonly occur in the phyllite. The Shemshak Formation nonconformably covers the unit.

A sub-horizontal foliation, S1, defined by very fine-grained chlorite and sericite and forming a pervasive slaty cleavage, is present in the metapelites and is gently folded by a second deformational event $\left(\mathrm{D}_{2}\right)$, accompanied by the formation of $\mathrm{S}_{2}$, a spaced fracture cleavage (Fig. 5g) related to kink bands and small scale chevron folds. Where the metamorphic grade increases, the $S_{1}$ foliation is marked by the preferred orientation of sericitic white mica, quartz and albitic plagioclase. A penetrative foliation is also present in the meta-volcanic rocks. The $\mathrm{S}_{1}$ foliation is generally subhorizontal, showing open ENE-WSW trending $\mathrm{D}_{2}$ folds with a kilometric wavelength. Structural analyses performed along the Radekhan fault (Fig. 4) indicate a strong deformation of the Gorgan Schists in the hanging wall accompanied by S-C shear structures. Tight to isoclinal folds occur in the lower part of the Carboniferous Mobarak Formation along the footwall of the fault (Figs 3, 4).

Available K-Ar whole-rock radiometric data of samples from the Gorgan Schists (Delaloye et al. 1981) cluster between 250 and 200 Ma, confirming an "EoCimmerian" age for the metamorphism and deformation of the complex.

The Gorgan Schists have yielded poorly preserved acritarchs, chitinozoa, scolecodonts and cryptospores (Fig. 6), the first three groups indicating deposition in a marine environment. Acritarchs from the Gorgan Schists in the Neka valley, from Kond-Ab towards the bottom of the valley, Mile Radkan, include Veryhachium sp., with representatives of the $V$. lairdii and $V$. trisipinosum groups, ?Actinotodissus crassus, Diexallophasis cf. denticulata, and a variety of acanthomorphs (samples 
79MH164 and 2001,js,ksg,1-11). Also present are chitinozoa, including

?Belonechitina sp. and Desmochitina sp. (sample 2001,js,ksg,9), and cryptospore tetrads (samples 79MH164, 2001,js,ksg,3). Similar assemblages were recorded from a further two samples. One, from a locality close to the Radekan Tower (GO5; 36³7'45',; 5406'18'’), yielded the acritarchs ?Tylotopalla caelamenicutis and Cymatiosphaera? or Dictyotidium?, together with sphaeromorph and acanthomorph acritarchs and possible cryptospore dyads and tetrads. The second sample, from the Ziarat Valley, south of Gorgan (GO44; 3649’19’', 54²9’05’'), yielded Veryhachium trispinosum? and acanthomorph acritarchs, specimens of ?Belonechitina, scolecodonts and possible cryptospore dyads. Tylotopalla caelamenicutis ranges from the latest Ordovician (post-glacial Hirnantian Stage; Vecoli \& Le Hérissé 2004, fig. 6) to the mid Silurian; it has not been recorded above the Llandovery in the Middle East (Jordan, Saudi Arabia; Keegan et al. 1990, Le Hérissé et al. 1995), but has been recorded from the Wenlock at lower palaeolatitudes (Welsh Borderland, Gotland: Dorning 1981; Le Hérissé 1989). Its occurrence suggests a latest Ordovician to early or mid Silurian age. The specimens of ?Actinotodissus crassus and Diexallophasis also support this age determination. Both appear in the Late Ordovician (Caradoc and Ashgill respectively; Vecoli \& Le Hérissé 2004, fig. 6), but ?A. crassus is restricted to the Late Ordovician whereas Diexallophasis ranges into the Devonian. The specimens of ?Belonechitina from GO44 are similar in some respects, notably in their size and the nature and distribution of their ornament, to Belonechitina paravitrea, a species recorded from the Llandovery (Rhuddanian-Aeronian) of Saudi Arabia (Paris et al. 1995, Paris \& Al-Hajri 1995). The genus Belonechitina ranges from the early Ordovician (Arenig Series) to the Upper Silurian (Ludlow Series). The palynological evidence thus suggests a Late Ordovician to possible Early Silurian depositional age for the Gorgan Schists.

\subsubsection{The Palaeozoic to Triassic succession of the Neka Valley}

An intensively folded and faulted succession ranging in age from Devonian to Middle Triassic is exposed along the Neka Valley between the Radekhan and the North Alborz Faults (Fig. 3). Devonian rocks of the Kosh Yeilagh Formation include wellbedded limestone, shale, sandstone, dolostone and diabase, and are covered by the Lower Carboniferous Mobarak Formation with marly limestone at the base passing to well-bedded dark limestone at the top. The Quezel Qaleh Formation (mid 
Carboniferous) follows with carbonate and terrigenous facies. The Permian successions include at the base the Dorud Formation with red conglomerate, sandstone, silty limestone and limestone with fusulinids. Bedded to massive limestone of the Ruteh Formation and the dolomitic limestone and dolostone of the Elika Formation follow up-section.

High-angle faults and intensive folding with steep axial planes intensely deform the whole Palaeozoic to Early-Middle Triassic succession exposed between the Gorgan Schists and the North Alborz Fault (Figs 4, 5). The occurrence of a regional Mesozoic unconformity, which cuts all these structures, demonstrates that they formed during the Eo-Cimmerian orogeny. Flat-lying, gently deformed Mesozoic deposits (Shemshak Formation, Lar Limestone and Ghalimoran Formation) unconformably cover previous faults and folds affecting the Gorgan Schists and the Palaeozoic to Middle Triassic deformed succession. This unconformity is well exposed along the middle-upper Neka valley, where we have focused our attention on the description of the Cimmerian deformation.

Folding style strongly depends on competence contrasts and bedding thickness of the folded multilayer, which included very different lithologies. Short decametric to heptometric, tight to isoclinal folds with very steep axial planes developed within the well-bedded limestone of the Mobarak Formation (Fig. 5c, 5d, 5f). Open ramp anticlines and chevron folds with a heptometric wavelength and amplitude formed in the carbonates of the Elika Formation due to parallel folding (Fig. 5b). Overturned folds in the Ruteh Limestone are faulted against the Devonian units north of the Talambar Fault in the upper part of the Neka valley (Fig. 5a). Parallel folding and a poorly developed axial plane disjunctive cleavage suggest that deformation occurred at shallow crustal levels. The Santonian Ghalimoran Formation, which only shows gentle folds (Fig. 7), unconformably covers everywhere these structures.

South of the North Alborz Fault, where stratigraphic relationships are preserved and the effects of the Eo-Cimmerian event are less intense, the Shemshak Formation forms a low angle unconformity with the underlying successions.

\subsubsection{The Cimmerian unconformity and the post-Elika Mesozoic succession}

The non-conformity between the Gorgan Schists and the Shemshak Formation is well exposed SW of Gorgan close to the village of Ramedan. Here, it consists of flat-lying 
coarse conglomeratic layers rapidly passing to marine bioclastic sandstone, unaffected by metamorphism. The Upper Jurassic Lahr Formation and the Ghalimoran Limestone also cover the metamorphic complex. Eastward (Neka Valley), the Shemshak Formation is absent and both the Palaeozoic units and the Gorgan Schists are directly covered and sealed by the Ghalimoran Formation (Figs 4, 5). The absence of the Mesozoic pre-Upper Cretaceous succession suggests the occurrence of topographic highs representing relief of the Eo-Cimmerian belt, which were surrounded by a shallow sea for most of the Mesozoic age (Berra et al. 2007).

\subsection{The Talesh Mountains (western Alborz)}

Although evidence of the Eo-Cimmerian orogeny is clearly recognizable in the Talesh Mountains (western Alborz), the strong tectonic imprint acquired during the Tertiary and Quaternary evolution of the belt strongly obscures the geometrical relationships among the Eo-Cimmerian units. Primary contacts among the internal and external units of the belt are not so clearly preserved as in central-eastern Alborz. We have focused our work (Fig. 8) on two main Eo-Cimmerian tectonic units located west of Rasht (Geological Survey of Iran 1975, 1977). They include: (1) the Shanderman Complex; and (2) a LG-metamorphic rock association with Late Palaeozoic slates and limestones. The non-metamorphic Shemshak Formation, dating from the Jurassic (Davies et al. 1972), non-conformably covers both the units.

\subsubsection{The Shanderman Complex}

The Shanderman Complex outcrops in small erosional windows below the Mesozoic units between the Rud-e-Masal (Masal Valley) and Asalem $50 \mathrm{~km}$ to the north (Figs 2, 8). Conglomerates and sandstones of the Shemshak Formation non-conformably cover the Shanderman Complex in most of the area. The basal conglomerates of the Shemshak Formation contain clasts of serpentinites, eclogites and other metamorphic rocks coming from the Shanderman Complex, testifying to its exposure during the Early Jurassic, after the end of the Eo-Cimmerian orogeny. The complex is generally separated from the Palaeozoic sedimentary cover of North Iran by steep strike-slip faults.

The Shanderman Complex mainly includes micaschists and metabasites with only minor calcschists, quartzites and phyllites (Lachur Rud). The metabasites of this complex are affected by two main deformational events. The first one produced a 
pervasive foliation under eclogitic conditions; the second one is responsible for the crenulation of the previous structures, and it is locally associated with an axial plane foliation, developed under amphibolite-facies conditions. Gabbro-dioritic intrusive bodies rich in ultramafic cumulates intrude the metamorphic basement of the Shanderman Complex after the main deformational events. These intrusive rocks often display a layered structure, including cumulitic dunites and peridotites. WNW-ESE and NNW-SSE trending high-angle shear zones, few to several metres thick, with respectively left- and right-lateral motions, cross the whole complex, causing deep fracturation and alteration of the intrusives. The ultramafic cumulates often display a pervasive serpentinization, which masks the original magmatic fabric. Mafic and ultramafic cumulates are also heavily serpentinized close to the contacts with the surrounding eclogites and micaschists. Poor outcrop conditions and a thick forest cover do not allow definition of the relationships between igneous rocks and the enclosing metamorphic rocks, even if the contacts seem to be of intrusive type with only minor shearing along the main faults. Thermobarometric estimates made on eclogites point to peak metamorphic conditions of $600-700^{\circ} \mathrm{C}$ and $\mathrm{P}>1.5 \mathrm{GPa}$ with a subsequent re-equilibration at garnet- to epidote-amphibolite facies conditions (Zanchetta et al., this volume). Ar-Ar dating of white mica separates gives a mid Carboniferous age (330 Ma, Zanchetta et al., this volume), slightly younger than the Middle to Late Devonian age obtained by Crawford (1977) for the phyllites of the Gasht Complex.

Whole rock chemical data of the Shanderman eclogites and mafic intrusives indicate a transitional to continental affinity (Zanchetta et al., this volume). These data, together with the age of metamorphism and the non-oceanic character of the serpentinized peridotites, here interpreted as altered ultramafic cumulates of igneous origin, suggest that the Shanderman Complex does not correlate with the Eo-Cimmerian Paleothetys suture zone, as it may represent a nappe of European Variscan continental crust stacked on the North Iran margin.

\subsubsection{The Late Palaeozoic Nappes}

A continuous belt of very low-grade metamorphic and non-metamorphosed but strongly deformed rocks, possibly belonging to the northern margin of the Iran block, occurs south and west of the Shanderman Complex (Fig. 8). We distinguished here 
two main tectonic units: 1) the Boghrov Dagh Unit, including a non-metamorphic Palaeozoic succession rich in volcanic layers; 2) the Masuleh-Shah Rud Unit, with low-grade metapelites and Upper Palaeozoic metacarbonates. Closed folds with a well-developed axial plane cleavage occur everywhere in this unit around Masuleh, and along the lower part of the Shah Rud. The Shemshak Formation unconformably covers part of this belt, indicating that these rocks were deformed during the EoCimmerian event. Mountain-scale exposures of the unconformity occur around the Shah Rud downstream of Shal (Fig.9a), around the village of Masuleh, along the Rude-Eskilit north of Masuleh, where an undeformed pre-Shemshak dioritic body also occurs (Fig. 8), and in the upper reaches of the Siava Rud gorge (Fig.9b).

Two geological cross-sections describe the structural setting of this area. The first one (Fig. 10) crosses the South Boghrov Dagh thrust sheet, consisting of a Neogene SW-vergent overturned faulted fold, complicated by minor thrusts, deforming a peculiar Palaeozoic succession which is thrust southward on the Mesozoic units. The frontal thrust of the Boghrov Dagh structure is Tertiary in age, as Neogene sediments are involved in these structures to the west, along the continuation of the main fault. The Palaeozoic succession forming the hanging wall includes a Silurian Orthoceraslimestone and thick Devonian basic lava flows and limestone, covered by a thick massive Carboniferous limestone rich in brachiopods, passing to thin layers of a possibly Permian fusulina-bearing limestone. The Shemshak Formation covers the succession with a low-angle unconformity. In the eastern part of the cross-section, the thick Mesozoic units mask the Shanderman Complex east of the Urma Rud. The sheared serpentinitic bodies exposed along the NW-SE faults following the eastern margin of the Boghrov Dagh Unit (Geological Survey of Iran 1975) belong to the layered intrusive complex described in the previous section.

The second cross-section (Fig. 10) shows a LG metamorphic unit, which is very different in composition from the Boghrov Dagh thrust sheet to the north and from the units exposed to the south. It mainly includes slates with strongly recrystallized carbonatic massive layers, in which Davies et al. (1972) identified PermoCarboniferous faunas. Folds measured in the slate just above the village of Masuleh below the Shemshak Formation, and along the Shah Rud in a similar position show NS trending axes and vertical axial planes with a pervasive slaty cleavage (Fig. 11). These trends strongly differ from the dominating NW-SE trends of the Tertiary folds 
(Fig.11). The Eo-Cimmerian unconformity outcrops along the upper part of the Siava Rud close to the summer village of Yeilagh (Fig. 9b). The Mesozoic cover present along the axis of the Shah Rud Valley generally hides the boundary between the two units. A NW-SE trending vertical fault zone with strongly deformed tectonic slices of the Shemshak Formation separates this nappe from the southernmost unit, consisting of an Upper Palaeozoic succession - here named Sureh Khani Unit - thrust on the Tertiary successions exposed along the Gezel Owzen Valley. An overturned fold with a steep NE-dipping axial plane complicated by minor thrusting and disharmonic parasitic folding occurs in the hanging wall of the main thrust, which is Late Tertiary in age, as suggested by the occurrence of progressively folded Neogene beds in the frontal part of the structure along the Qezel Owzen Valley.

\subsection{The Eo-Cimmerian structures in the central Alborz foreland}

The North Alborz Fault marks the boundary between the Eo-Cimmerian orogen and the stable foreland of North Iran, which now forms most of the central Alborz. To the south of this fault, the Shemshak Formation covers the pre-Middle Triassic successions with a low angle unconformity (Assereto 1966a) or conformably (Ghasemi-Nejad et al. 2004). According to most authors, the deposition of the Shemshak Formation on the undeformed foreland marks the erosion of the EoCimmerian orogen, growing due to the progressive collision of Iran with the southern Eurasian margin. Change from the carbonate platform of the Elika Formation to continental to marine silicoclastic depositional systems occurred between the end of the Carnian and the beginning of the Norian (Ghasemi-Nejad et al. 2004).

Eo-Cimmerian graben and half-graben occur within central Alborz, predating the deposition of the Shemshak Formation in the Shemshak region (Zanchi et al. 2006). Here an E-W trending isolated ridge consisting of the Permo-Triassic carbonates of the Ruteh and Elika Formations, previously described as an isolated thrust sheet (the Shahrestanak klippe of Assereto 1966b), has been now interpreted as a reactivated extensional structure together with the Gajereh half-graben present a few kilometres to the north. The occurrence of the Elika Formation only within the two grabens, whereas outside the Shemshak Formation directly covers the Palaeozoic succession suggests that normal faulting occurred after the deposition of the Elika Formation during Middle-Late Triassic times before the deposition of the Cimmerian-related 
clastics. Coincidence of the extensional event with the Eo-Cimmerian orogeny suggests that this can be an effect of the peripheral bulging of the foreland induced by the collision. These extensional structures were inverted during the Meso-Cenozoic tectonics that affected the Alborz, accounting for many of the peculiar characters of the belt (Zanchi et al. 2006).

\section{Petrographic analysis of the Shemshak sandstones}

The basal beds of the Shemshak Formation were sampled in different portions of the Eo-Cimmerian belt. Description of the samples is reported in Appendix 1. The petrographical composition of the Shemshak sandstones (Table 1) is distinct in the three sampled areas: a) Kandavan Pass (external foreland; samples IR4, IR5, IR6, IR7); 2) Masulé-Talesh (internal part of the belt; samples TZ2, IR8, IR9); 3) Neka Valley (internal part of the belt; samples GO29, GO32, GO33).

\section{Provenance interpretation}

Quartzolithic composition of all Shemshak Formation sandstones (Fig. 12) indicates a “Recycled Orogenic Provenance” (Dickinson 1985; Garzanti et al. 2007).

In the Kandavan area, the Shemshak sandstones represent the relatively distal remnant of the Eo-Cimmerian foreland basin (Fig. 13a). Their homogeneous quartzolithic composition with diverse types of rock fragments suggests deposition by a significant palaeoriver, draining a considerably part of the Eo-Cimmerian belt. The latter, at Shemshak times, largely consisted of cover units including volcanic, sedimentary, and very low-grade metasedimentary rocks. Composition of the Kandavan sandstones differs from the quartzolithic Shemshak sandstones in the Shemshak type area (Assereto 1966a, p.1144) because the latter are more quartzose and lack volcanic rock fragments, indicating provenance chiefly from sedimentary cover units. In the Talesh area, the Shemshak sandstones non-conformably overlie a thrust stack characterized by very low- to low-grade and are associated with coarse-grained conglomeratic deposits. Their lithic composition (Fig. 13b, 13c) indicates relatively local provenance from cover units, including very-low grade metasedimentary rocks as well as unmetamorphosed felsic volcanic and sedimentary rocks (dolostone, shale/sandstone, and chert). In the Ramedan area (Fig. 13d), the Shemshak sandstones and very coarse-grained conglomerates nonconformably overlie the 
Gorgan Schists. Their composition is virtually pure metamorphiclastic. The metamorphic grade of metapelite/metapsammite source rocks varies from anchimetamorphic to lower greenschist-facies up section. This is consistent with deposition in proximal settings by a minor transverse river.

Compositional variability of the Shemshak sandstones depends not only on provenance, but also markedly on grain-size. The analysed very fine grained sandstone in the Talesh area (IR8) and coarse siltstone in the Ramedan area (GO29), in fact, display a strong to very strong enrichment in monocrystalline quartz (probably largely recycled from older quartzose sandstones) at the expense of rock fragments.

\section{Discussion}

The data collected in the Alborz and Talesh Mountains provide a new interpretation of the remnants of the Eo-Cimmerian orogen. In the Neka Valley, south of Gorgan, a complete section of the Eo-Cimmerian belt is exposed. The section includes the Gorgan Schists, a Lower Palaeozoic meta-sedimentary and meta-volcanic succession which was deformed and metamorphosed around $200 \mathrm{Ma}$, as well as the Upper Palaeozoic and Lower-Middle Triassic successions of North Iran, which are strongly deformed but lack significant metamorphism. The occurrence of generally flat-lying undeformed Mesozoic successions (from the Shemshak to the Santonian Ghalimoran Formation), unconformably overlying these units testifies that their deformation is EoCimmerian in age. Our new interpretation is in disagreement with previous works, such as that of Alavi (1996), who suggested the occurrence of a low angle normal detachment between the Cretaceous undeformed formations and the underlying units. However, a basal sandy layer, rich in glauconitic grains occurs in most of the analysed outcrops at the base of the Upper Cretaceous unit, and no evidence of regional faulting has been observed (Berra et al. 2007). Although Silurian volcanic rocks occur in the Palaeozoic units of the northernmost part of Iran (Jenny \& Stampfli 1978), no thick terrigenous successions similar to the one forming the Gorgan Schists is known to the south, preventing a direct correlation with the Palaeozoic of the Iranian margin.

In the Talesh Mountains, the structural framework is much more complex, as Tertiary and Quaternary thrusting and faulting strongly dismembered the Eo-Cimmerian orogen. However, the occurrence of very low-grade Upper Palaeozoic metasediments 
forming the Masuleh-Shah Rud tectonic unit and lying below the poorly deformed Shemshak Formation unequivocally indicates the occurrence of an important EoCimmerian orogenic event, also in the Talesh Mountains. This unit, which crops out in a more external position with respect to the Boghrov Dagh thrust sheet - which does not record an Eo-Cimmerian metamorphic event - is problematic. Out-ofsequence thrusting or intensive faulting at the end of the Eo-Cimmerian event could explain this intricate structural setting.

Additional information comes from the analysis of the Shanderman Complex (see also Zanchetta et al., this vol.), which includes gabbros with ultramafic cumulates intruding a metamorphic basement with metapelites and eclogites. Magmatic rocks do not show a significant metamorphic overprint. The association of eclogitic rocks with a metapelitic complex point to continental crust rather than to subducted oceanic sea floor, as previously suggested by Alavi (1996). The exhumation of the Shanderman Complex definitively occurred at the end of the Eo-Cimmerian orogeny, as suggested by the Early Jurassic age of the Shemshak Formation (Clark et al. 1972), which unconformably covers these rocks. In addition, Ar-Ar radiometric ages (Zanchetta et al., this volume) suggest a mid Carboniferous age for the eclogitic peak metamorphic conditions.

High-pressure eclogitic metamorphic rocks with Late Devonian and Carboniferous ages (Philippot et al. 2001; Kazmin 2006; Saintot et al. 2006) occur in the Caucasian region. These authors relate the high-pressure event to the accretion of a microplate detached from Gondwana at the beginning of the Palaeozoic to the southern margin of the Schythian Platform, with the closure of the Protothethys Ocean. The colliding microplate included two main blocks separated by a back-arc basin. The Makera block was located to the north and the Pontian-Transcaucasian block to the south, the latter being the northern active margin of the Palaeotethys during the Middle Carboniferous (Kazmin 2006). High-grade metamorphics of the Chorchana-Utslevi zone intruded by "Variscan granitoids" are described in the Dzirula Massif of the Transcaucasian region (Sengor 1990). This unit also includes Silurian to Devonian phyllites and sheared serpentinites, possibly representing a dismembered ophiolite. Further evidence of a Carboniferous orogenic activity comes from the Khrami Salient and Loki Massif belonging to the same area, where respectively andalusite-sillimanite gneisses and greenschists to epidote amphibolite metamorphic rocks are intruded by 
Lower and mid Carboniferous granitoids. The radiometric ages summarized by Sengor (1990 and references therein) suggest that metamorphism, magmatism and deformation span the entire Carboniferous. We thus suggest that the Shanderman and Gasht complexes may represent fragments of large nappes of Variscan continental crust coming from the Transcausian area, or from its lateral extension along the present-day region of the South Caspian Sea. These nappes were overthrusted southward on the northern margin of North Iran during the Eo- Cimmerian orogeny. The polyphase formation of the Caspian Sea (Brunet et al. 2003; Brunet et al., this volume) following the Eo-Cimmerian collision and the Neogene SSW-vergent thrust stacking may account for the large displacement of these units from their initial position. N-S trending dextral strike-slip faults (Figs 2, 8), forming the western margin of the Talesh Mountains, have probably accommodated the later displacements of the thrust sheets.

The Eo-Cimmerian compressive structures are restricted to the Talesh Mountains and to the Gorgan region. Central Alborz corresponds in large part to the foreland of the Eo-Cimmerian belt (Zanchi et al. 2006), where the formation of extensional structures during Middle-Late Triassic is related to peripheral bulging along the southern margin of the foreland basin (Fig.14). Here the Shemshak Formation conformably covers the Lower to Middle Triassic carbonates of the Elika Formation (GhasemiNejad et al. 2004), or it overlies it with a low-angle unconformity. The petrographic composition of the Shemshak Formation records the unroofing of the Eo- Cimmerian orogen since the Norian. Thickness variations, facies complexity and strong differences in the age of its base indicate a greater complexity for the "Eo-Cimmerian molasse”, which is discussed by Fursich et al. (this volume).

\section{A comparison with the evolution of the Palaeotethys suture in NE-Iran}

The evolution of the Alborz sector of the Eo-Cimmerian orogen can be compared with the one of the Paleotethys suture zone (Fig. 1) extending between Mashad and TorbatJam (Stocklin 1974; Alavi 1991; Boulin 1991; Ruttner 1993; Geological Survey of Iran 1986, 1993, 1996; Alavi et al. 1997). The Palaeotethys remnants are well exposed close to Mashad, in the Binalood Mountains, where an accretionary wedge with ophiolitic fragments unconformably rests below undated coarse conglomerates and sandstones with plant remains doubtfully assigned to the Late Triassic Early 
Jurassic time interval (Alavi, 1991). The Middle Jurassic Kashaf Rud Formation in turn covers these deposits.

To the south, the accretionary wedge extends eastward to the Afghan Border (Fig. 2) forming an ESE-WNW trending strip of pillow lavas, ultramafics, turbidites, Permian limestones and cherts intruded by Late Triassic-Early Jurassic granitoids (Geological Survey of Iran 1993). A thick succession of continental red conglomerates capped by latest Permian limestones rests on top of the external parts of the complex (Alavi et al. 1997). The northern part of the area includes the "Aghdarband basin" (Fig. 2, 15) with Lower to Middle Triassic continental to deep marine sediments and acidic volcanoclastic rocks at the top deposited in a deep faultcontrolled intra- or back-arc basin (Ruttner 1993; Alavi et al. 1997). The Norian coal-bearing Miankhui Formation covers the Aghdarband basin without a marked angular unconformity. The whole succession is strongly deformed in a north-verging thrust stack crossed by leftlateral strike-slip faults. The basement of the Aghdarband basin consists of Upper Palaeozoic very LG metasediments and metavolcanics belonging to the Turan domain and related to the growth of volcanic arcs along the southern part of Eurasia (Alavi et al. 1997). The Middle Jurassic sediments of the Kashaf Rud Formation unconformably cover all the described units after their deformation.

Evidence of a Palaeotethys suture with ophiolitic units s.l. is thus restricted to the northeast of Iran (Mashad region), whereas they are not preserved in the Alborz. Here, the Eo-Cimmerian collision of North Iran with Eurasia resulted in the formation of a stack of metamorphic nappes consisting entirely of continental crust partially involved in a subduction process during the Carboniferous and possibly belonging to the southern portion of Transcaucasia. In addition, low-grade metamorphic rocks with Palaeozoic protoliths record a LG metamorphic event directly related to the EoCimmerian orogeny. Radiometric ages constrain the event between 250 and 200 Ma. The occurrence of a collisional orogen is also recorded by the deposition of the Shemshak Formation, beginning in the foreland since the Norian (Fig. 15). From Mashad and to the east, accretionary phenomena are recorded from the Permian to the Middle Triassic. The last deformational event, possibly marking the collision of the northern part of Central Iran, occurs between the Raethian and the beginning of the Middle Jurassic and is thus younger than in the Alborz. 
The different tectono-stratigraphic histories recognized in the Alborz and in the Mashad region can be mainly ascribed to the heterogeneous composition of the southern margin of Eurasia as well as to its irregular shape. According to Garzanti \& Gaetani (2002), the Late Palaeozoic southern margin of Eurasia consisted of a mosaic of small and mobile continental blocks separated by accretionary wedges, back-arc basins and transform faults. The occurrence of a rigid block in front of the Alborz, possibly representing the southern part of Transcaucasia, which was already accreted to Eurasia during the Carboniferous, may account for an earlier collision with Iran, causing a complete consumption of the Palaeotethys lithosphere. To the west, the occurrence of mobile blocks represented by Late Palaeozoic volcanic arcs and backarc basins south of Mangyslak, in front of the Mashad-Torbat Jam region, may have accommodated the deformation in a wider collisional zone, which is partially preserved, and a time-shift of the final deformation that also affects the Norian Mainkuhi Formation. Other effects such as the occurrence of a deep embayment along the northeastern edge of Iran, as well as a partially oblique collision, could also explain the different characters of the Eo-Cimmerian orogeny along the northern margin of Iran.

\section{Acknowledgements}

This work was funded by the MEBE project (proposal 02-26, Meso-Cenozoic evolution of the Alborz mountain range, Iran) and by an Italian MURST PRIN Project (2004-2006, leader A. Zanchi) in collaboration with the Geological Survey of Iran. Dr. M.R. Ghasemi, Dr. A. Saidi and his colleagues of Geological Survey of Iran are warmly thanked for continuous help and assistance in the field. Irene Bollati counted sandstones at the Milano-Bicocca University.

\section{References}

Alavi, M. 1991. Sedimentary and structural characteristics of the Paleo-Tethys remnants in northeastern Iran. Geological Society of American Bulletin 103, 983992.

Alavi, M., 1996. Tectonostratigraphic synthesis and structural style of the Alborz Mountain System in Iran. Journal of Geodynamics 21/1, 1-33. 
Alavi, M., Vazir, H., Seyed-Emami, K., Lasemi, Y. 1997. The Triassic and associated rocks of the Nakhlak and Aghdarband areas in central and northeastern Iran as remnants of the southern Turanian active continental margin. Geological Society of America Bulletin, 109, 1563-1575.

Allen, M.B., Ghassemi, M.R., Shahrabi, M. \& Qorashib, M. 2003a. Accommodation of late Cenozoic oblique shortening in the Alborz range, northern Iran. Journal of Structural Geology 25, 659-672.

Allen, M. B., Vincent, S. J., Alsop, G.I., Ismail-zadeh, I., Flecker, R., 2003b. Late Cenozoic deformation in the South Caspian region: effects of a rigid basement block within a collision zone. Tectonophysics 366, 223- 239.

Angiolini, L., Gaetani, M., Mattoni, G., Stephenson, M.H. \& Zanchi, A. 2007. Tethyan oceanic currents and climate gradients 300 m.y. ago. Geology 35, 10711074.

Assereto, R. 1966a. The Jurassic Shemshak Formation in central Alborz (Iran). Rivista Italiana di Paleontologia e Stratigrafia 72, 1133-1182.

Assereto, R., 1966b. Explanatory notes of the geological map of upper Djadjerud and Lar valleys (Central Alborz, Iran). Istituto di Geologia, Università di Milano Serie G., pubblicazione 232, Milano, Italy.

Axen, G. J., Lam, P.S. Grove, M., Stockli, D.F., Hassanzadeh, J. 2001. Exhumation of the west-central Alborz Mountains, Iran, Caspian subsidence, and collision-related tectonics. Geology 29/6, 559-562.

Berberian, M. \& King, G. 1981. Toward a paleogeography and tectonic evolution of Iran. Canadian Journal of Earth Science, 18, 210-265.

Berra, F., Zanchi, A., Mattei, M. \& Nawab A. 2007. Late Cretaceous transgression on a Cimmerian high (Neka Valley, Eastern Alborz, Iran): A geodynamic event recorded by glauconitic sands. Sedimentary Geology, 199 , 189-204.

Besse, J., Torcq, F., Gallet, Y., Ricou, L.E., Krystyn, L. \& Saidi A. 1998. Late Permian to Late Triassic palaeomagnetic data from Iran: constraints on the migration of the Iranian block through the Tethyan Ocean and initial destruction of Pangaea. Geophysical Journal International, 135, 77-92. 
Boulin, J., 1988. Hercynian and Eocimmerian events in Afghanistan and adjoining regions. Tectonophysics, 148, 253-278.

Boulin, J., 1991. Structures in Southwest Asia and evolution of the eastern Tethys. Tectonophysics, 196, 211-268.

Brunet, M.F., Korotaevb, M.V., Ershovb, A.V., Anatoly M. \& Nikishin A.M. 2003. The South Caspian Basin: a review of its evolution from subsidence modelling. Sedimentary Geology, 156, 119-148.

Clark, G.C., Davies, R.G., Hamzepour, G. \& Jones, C.R. 1975. Explanatory text of the Bandar-e-Pahlavi quadrangle map, 1:250,000. Geological Survey of Iran, Tehran, Iran, pp.198.

Crawford, M.A. 1977. A summary of isotopic age data for Iran, Pakistan and India. In : Libre a la memoire del A.F. de Lapparent. Mémoire hors-serie 8. Societé Géologique de France, 251-260.

Davies, R.G., Jones, C.R., Hamzepour, B. \& Clark G.C. 1972. Geology of the Masuleh sheet, 1:100,000, NW Iran. Geological Survey of Iran, Report 24, pp.110.

Delaloye, M., Jenny, J. \& Stampfli G. 1981. K-Ar dating in the eastern Elburz (Iran). Tectonophysics, 79, 27-36.

Dercourt, J., Gaetani, M., Vrielynck, B., Barrier, E., Biju-Duval, B., Brunet, M.-F., Cadet, J.-P., Crasquin, S. \& Sandulescu, M. 2000. Atlas Peri-Tethys.

Palaeogeographical Maps. CCGM/CGMW, Paris (24 maps and explanatory notes: I -XX; 269 pp).

Dickinson, W. R. 1985. Interpreting provenance relations from detrital modes of sandstones. In Zuffa, G. G. (ed) Provenance of arenites. Dordrecht, Reidel Publ., NATO ASI Series 148, 333-361.

Dorning, K. J. 1981. Silurian acritarchs from the type Wenlock and Ludlow of Shropshire, England. Review of Palaeobotany and Palynology, 34, 175-203.

Fursich, F.T., Wilmsen, M., Seyed-Emami, K., Cecca, F. \& Majidifard, R., 2005. The upper Shemshak Formation (Toarcian-Aalenian) of the Eastern Alborz (Iran): Biota and palaeoenvironments during a transgressive-regressive cycle. Facies 51, 365-384. 
Garzanti, E. \& Vezzoli, G. 2003. A classification of metamorphic grains in sands based on their composition and grade. Journal of Sedimentary Research, 73, 830-837. Garzanti, E., Andò, S. \& Vezzoli, G. 2006. The Continental Crust as a Source of Sand (Southern Alps cross-section, Northern Italy). Journal of Geology, 114, 533-554.

Garzanti, E., Doglioni, C., Vezzosi, G. \& Andò, S. 2007. Orogenic Belts and Orogenic Sediment Provenances. Journal of Geology, in press.

Garzanti, E. \& Gaetani, M. 2002. Unroofing history of Late Palaeozoic magmatic arcs within the 'Turan Plate' (Tuarkyr, Turkmenistan). Sedimentary Geology, 151, 67-87.

Ghasemi-Nejad, E., Agha-Nabati, A. \& Dabiri O., 2004. Late Triassic dinoflagellate cysts from the base of the Shemshak Group in north of Alborz Mountains, Iran. Review of Palaeobotany and Palynology, 132, 207- 217.

Ghasemi, A. \& Talbot, C. J. 2006. A new tectonic scenario for the Sanandaj-Sirjan Zone (Iran). Journal of Asian Earth Sciences, 26, 683-693.

Geological Survey of Iran 1975. Geological Map of the Masuleh area. Geological Survey of Iran, Tehran, scale 1:100,000.

Geological Survey of Iran 1977. Bandar-e-Pahlavi. Geological Survey of Iran, Tehran, scale 1:250,000.

Geological Survey of Iran 1985. Qazvin and Rasht. Geological Survey of Iran, Tehran, scale 1:250,000.

Geological Survey of Iran 1986. Mashad. Geological Survey of Iran, Tehran, scale $1: 250,000$.

Geological Survey of Iran 1987. Tehran. Geological Survey of Iran, Tehran, scale 1:250,000.

Geological Survey of Iran 1988. Semnan. Geological Survey of Iran, Tehran, scale $1: 250,000$.

Geological Survey of Iran 1989. Geological Map of Iran. Geological Survey of Iran, Tehran, scale 1:2,500,000.

Geological Survey of Iran 1991a. Amol. Geological Survey of Iran, Tehran, scale $1: 250,000$. 
Geological Survey of Iran 1991b. Gorgan. Geological Survey of Iran, Tehran, scale $1: 250,000$.

Geological Survey of Iran 1991c. Sari. Geological Survey of Iran, Tehran, scale $1: 250,000$.

Geological Survey of Iran 1993. Torbat-Jam. Geological Survey of Iran, Tehran, scale $1: 250,000$.

Geological Survey of Iran 1996. Mashad. Geological Survey of Iran, Tehran, scale $1: 100,000$.

Geological Survey of Iran 1997. Gorgan. Geological Survey of Iran, Tehran, scale 1:100,000.

Geological Survey of Iran 2001. Marzan Abad. Geological Survey of Iran, Tehran, scale $1: 250,000$.

Geological Survey of Iran 2004. Bandar-e-Anzali. Geological Survey of Iran, Tehran, scale $1: 100,000$.

Guest, B., Axen, G.J., Lam, P.S. \& Hassanzadeh, J. 2006a. Late Cenozoic shortening in the west-central Alborz Mountains, northern Iran, by combined conjugate strikeslip and thin-skinned deformation. Geosphere 2/1, 35-52; doi: 10.1130/GES00019.1.

Guest, B., Stockli D.F., Grove M., Axen, G.J., Lam, P.S. \& Hassanzadeh, J. 2006a. Thermal histories from the central Alborz Mountains, northern Iran: Implications for the spatial and temporal distribution of deformation in northern Iran. Geological Society of America Bulletin, 118, 1507-1521; doi: 10.1130/B25819.1.

Ingersoll, R. V., Bullard, T. F., Ford, R. L., Grimm, J.P., Pickle, J.D. \& Sares, S.W. 1984. The effect of grain size on detrital modes: a test of the Gazzi-Dickinson pointcounting method. Journal of Sedimentary Petrology, 54, 103-116.

Jackson, J., Priestley, K., Allen, M. \& Berberian, M. 2002. Active tectonics of the South Caspian Basin.Geophysical Journal International, 148, 214-245.

Jenny, J. \& Stampfli, G. 1978. Lithostratigraphie du Permien de l'Elbourz oriental en Iran. Eclogae geologicae Helveticae, 71, 551-580. 
Kazmin, V. G. 2006. Tectonic Evolution of the Caucasus and Fore-Caucasus in the Late Paleozoic. Doklady Earth Sciences, 406,. 1-3. Pleiades Publishing, Inc., ISSN 1028-334X.

Keegan, J., Rasul, S. M. \& Shaheen, Y. 1990. Palynostratigraphy of the Lower Palaeozoic, Cambrian to Silurian sediments of the Hashemite Kingdom of Jordan. Review of Palaeobotany and Palynology, 66, 167-180.

Le Hérissé, A. 1989. Acritarches et kystes d'algues Prasinophycées du Silurien de Gotland, Suède. Palaeontographia Italica, 76, 57-302.

Le Hérissé, A., Al-Tayyar, H. \& van der Eem, H. 1995. Stratigraphic and paleogeographical significance of Silurian acritarchs from Saudi Arabia. Review of Palaeobotany and Palynology, 89, 49-74.

Paris, F. \& Al-Hajri, S. 1995. New chitinozoan species from the Llandovery of Saudi Arabia. Revue de Micropaléontologie, 38, 311-328.

Paris, F., Verniers, J., Al-Hajri, S. \& Al-Tayyar, H. 1995. Biostratigraphy and palaeogeographic affinities of Early Silurian chitinozoans from central Saudi Arabia. Review of Palaeobotany and Palynology, 89, 75-90.

Philippot, P., Blichert-Toft, J., Perchuk, A., Costa, S. \& Gerasimov V. 2001. Lu-Hf and Ar-Ar chronometry supports extreme rate of subduction zone metamorphism deduced from geospeedometry. Tectonophysics, 342, 23-38

Ritz., J.-F., Nazari H., Ghassemi, A., Salatati R., Shafei A., Solaymani S. \& Vernant P. 2006. Active transtension inside central Alborz: A new insight into northern Iransouthern Caspian geodynamics. Geology, 34/ 6, 477-480; doi: 10.1130/G22319.1. Ruttner, A.W. 1993. Southern borderland of Triassic Laurasia in north-east Iran. Geologische Rundschau, 82, 110-120.

Saidi, A., Brunet, M.F. \& Ricou L.E. 1997. Continental accretion of the Iran Block to Eurasia as seen from Late Palaeozoic to early Cretaceous subsidence curves.

Geodinamica Acta, 10, 189-208.

Saintot, A., Stephenson, R. A., Stovba, S., Brunet, M.-F., Yegorova, T. \& Starostenko, V. 2006. The evolution of the southern margin of Eastern Europe (Eastern European and Scythian platforms) from the latest Precambrian-Early Palaeozoic to the Early Cretaceous. In: Gee, D. G. \& Stephenson, R. A. (eds) 2006. 
European Lithosphere Dynamics. Geological Society, London, Memoirs, 32, 481505; 0435-4052/06/\$15.00.

Sengor, A.M.C. 1979. Mid-Mesozoic closure of Permo-Triassic Tethys and its implications. Nature, 279, 590-593.

Sengor, A.M.C. 1984. The Cimmeride orogenic system and the tectonics of Eurasia. Geological Society of America Special Paper, 195, pp.82.

Sengor, A.M.C. 1990. A new model for the late Palaeozoic-Mesozoic tectonic evolution of Iran and implications for Oman. In: Robertson, A. H., Searle M. P. \& Ries A.C. (eds). The Geology and tectonics of the Oman region. Geological Society Special Publication, 49, 797-831.

Seyed-Emami, K. 2003. Triassic in Iran. Facies, 48: 95-106.

Stampfli, G.M., Marcoux, J. \& Baud, A., 1991. Tethyan margins in space and time. Palaeogeography, Palaeoclimatology, Palaeoecology, 87, 373-409.

Stocklin, J. 1974. Possible ancient continental margins in Iran. In: Burk, C.A.\& Drake, C.L. (eds). The geology of Continental Margins, 873-887. Springer-Verlag. Vecoli, M \& Le Hérissé, A. 2004. Biostratigraphy, taxonomic diversity and patterns of morphological evolution of Ordovician acritarchs (organic-walled microphytoplankton) from the northern Gondwana margin in relation to palaeoclimatic and palaeogeographic changes. Earth-Science Reviews, 67, 267-311. Weltje, G. J. 2002. Quantitative analisys of detrital modes: statistically rigorous confidence methods in ternary diagrams and their use in sedimentary petrology. Earth Science Reviews, 57, 211-253.

Wendt, J., Kaufmann, B., Belka, Z., Farsan, N. \& Bavandpur, A. K. 2005. Devonian/Lower Carbonifeous stratigraphy, facies patterns and palaeogeography of Iran Part II. Northern and Central Iran. Acta Geologica Polonica, 55/1, 31-97.

Wensink, H., Zijderveld, J.D. \& Varekamp, J.C. 1978. Paleomagnetism and ore mineralogy of some basalts of the Geirud Formation of late Devonian-early Carboniferous age from the southern Alborz, Iran. Earth Planetary Science Letters, 41, 441-450. 
Zanchi, A., Berra F., Mattei, M., Ghasemi, M.R. \& Sabouri J., 2006. Inversion

tectonics in Central Alborz, Iran. Journal of Structural Geology, 28, 2023-2037.

\section{APPENDIX 1 Petrographic description of the Shemshak sandstones}

\section{Kandavan sandstones}

Samples (IR4, 5, 6, and 7) have been collected along the Karaj-Chalus road $50 \mathrm{~m}$ above the basal layers of the formation in front of the coal mines located close to the junction-road to Elika. The four upper-fine to lower medium grained $(2.1 \pm 0.1 \Phi)$ sandstones have homogeneous quartzolithic composition (Q 60 \pm 2 , F 3 \pm 2 , L 36 \pm 3 ;

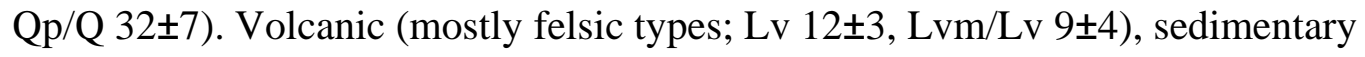
(mostly siltstone/shale with some radiolarian chert; Lp 15 \pm 4 , Lch 2 \pm 1 ) and metamorphic lithic grains (mostly very low-to-low rank metasedimentary; Lm $7 \pm 1$, MI 173 \pm 45 ) are all significant (Fig.13a). Plagioclase prevails among the few feldspars

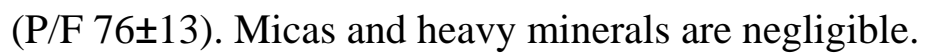

\section{Masulé-Talesh sandstones}

The two lower- medium-grained sandstones $(1.8 \pm 0.1 \Phi)$, sampling along the road above Masuleh (IR8, IR9), and along the Shah Rud downstream Kholur (TZ2) have

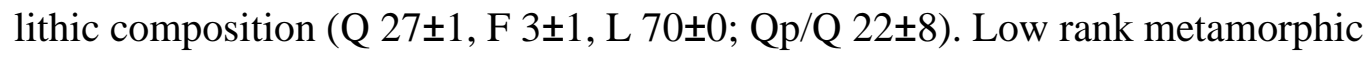

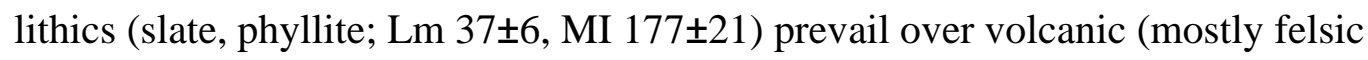

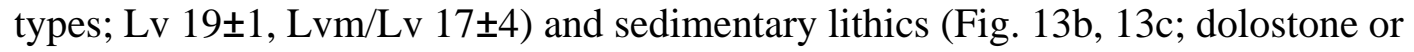
siltstone/shale, with minor chert; Lcd $\leq 17$, Lp $\leq 7$, Lch $1 \pm 0$ ). Plagioclase prevails among the few feldspars (P/F 75 \pm 0 ). Micas and heavy minerals are negligible. The very-fine-grained sandstone (3.2 Ф) sampled along the road above Masuleh is markedly enriched in monocrystalline quartz (Q 81, F 3, L 16; Qp/Q 11), and includes dominant phyllite metamorphic lithics (Lm 12, MI 223), a few felsic volcanic lithics (Lv 4, Lvm/Lv 11), and muscovite (2\%).

\section{Neka Valley sandstones}

Samples were collected from the right side of the Neka Valley, south of Gorgan close to the village of Ramedan. The two lower-fine-grained sandstones $(2.8 \pm 0.1 \Phi)$ have lithic to quartzolithic composition (GO31, GO32), dominated by low-rank (Fig. 13d; 
slate-arenite of Garzanti et al. 2006; Q 19, F 3, L 78; MI 227) to medium-rank metamorphic lithics (phyllitearenite of Garzanti et al. 2006; Q 48, F 2, L 50; MI 320). Micas are common (muscovite $3.5 \pm 0 \%$, biotite $2.5 \pm 2 \%$ ), and a few volcanic grains occur ( $\operatorname{Lv} 2 \pm 1)$.

The coarse siltstone sample GO29 (4.3 Ф) is strongly enriched in monocrystalline quartz, and includes some plagioclase and no lithic grains (Q 96, F 4, L 0; Qp/Q 4, P/F 82).

\section{Figure Captions}

Fig. 1. Tectonic scheme of Iran with the main tectonic subdivisions. The location of the Eo- Cimmerian units is shown with vertical dash. Black: Mesozoic ophiolites along the Main Zagros and other sutures. AMC: Anarak Metamorphic Complex. Modified from Angiolini et al. 2007.

Fig. 2. Structural map of the Alborz belt based on Geological Survey of Iran (1989) and on our observations. The two squares refer to the location of figures 3 and 8 .

Fig. 3. Simplified geological map of the Neka valley from Geological Survey of Iran (1997) modified basing on our data. Location within the Alborz belt, in figure 2. Stereographic projections refer to the structural analysis of the Eo-Cimmerian structures exposed along the Neka valley. Site Gorgan1Neka1 includes data on the Gorgan Schists measured south of the town of Gorgan (36²'59”; 54) and in the Neka valley (36³6’14”; 5349’51”) just west of figure 3, close to the bridge of the village of Sefecha. Small empty circle: pole to bedding So; pole to axial plane slaty cleavage of the $\mathrm{D}_{1}$ phase; black small circles: fold axes of the phase $\mathrm{D}_{2}$; grey small circles: pole to axial surface of the phase $\mathrm{D}$ 2. In the other plots thin lines are faults, black dots represent striations with relative sense of motion, square are poles to mylonitic foliation along the Radekan Fault. The other symbols refer to the same geometrical features but are all related to the $\mathrm{D}_{1}$ deformational event. Schmidt's projection, lower hemisphere.

Fig. 4. General composite sections across the Neka Valley; traces in figure 3. The EoCimmerian structures formed along the frontal part of the belt are preserved below the Mesozoic successions. Neogene reverse faults are also shown. GA: Ghalimoran 
Limestone (Late Cretaceous). See text for details. Geometry of the folds in the Gorgan Schists are partially inferred. Scales are different in the two sections.

Fig. 5. Field views of the Eo-Cimmerian structures and of the Upper Cretaceous unconformity in the upper Neka Valley. Compare with the Tertiary structures depicted in figure 6 for the different style of folding. (a): Eo-Cimmerian structures below the Ghalimoran Formation in the upper Neka Valley just north of the Tertiary Talanbar Fault; (b): folds and faults in the Elika Formation along the uppermost part of the Neka valley. Folds are entirely sutured by the Upper Cretaceous limestones; (c) and (d): the Upper Cretaceous unconformity sealing the Eo- Cimmerian structures along the middle Neka Valley. Structural data concerning the Eo- Cimmerian folds developed in the Mobarak Carboniferous limestones are reported in figure 3. (NEKA3 and NEKA6); (e): the Ghalimoran Limestone lays on a folded succession (NEKA9B in figure 3) of Palaeozoic Red Nodular Limestones of unknown age. A Tertiary (Neogene?) steep reverse fault is responsible for the uplift of the Permian Ruteh limestones along the hanging wall above the Ghalimoran Formation. Faults in plot NEKA9B (figure 3) crosscut the Eo- Cimmerian folds formed in the red limestones. Note the flat geometry of the unconformity surface; (f): a close view of the Upper Cretaceous unconformity. Note the flat geometry of the surface; (g): structural features of the Gorgan Schists in the Neka valley; two deformational events are shown.

Fig. 6. Microfossils (acritarchs, chitinozoans, cryptospores and scolecodont) from the Gorgan Schists. (1, 2): Tylotopalla caelamenicutis? Loeblich 1970. MPK 13545, sample GO5, England Finder co-ordinates M9/3. Figure 6.2 photographed using spot meter to show ornament of striae radiating from the bases of the processes. $(3, \mathbf{8})$ : acanthomorph acritarchs. (3): MPK 13546, slide MPA 55320/1, L29/0; (8): MPK 13547, sample GO5, Q18/4. (4, 5): Veryhachium trispinosum (Eisenack) Stockmans \& Willière 1962. (4): 79MH164 (33). (5): MPK 13548, sample GO44, G19/0. (6): Diexallophasis sp. cf. D. denticulata (Stockmans \& Willière) Loeblich 1970. 79MH164 (2). (7): Scolecodont. MPK 13552, sample GO44, G27/0. (9, 10): Cymatiosphaera? or Dictyotidium? MPK 13549, sample GO5, M61/0. Figure 6.10 photographed using spot meter to show reticulate ornament on the vesicle wall. Two orders of reticulate ornament resembling that of the Silurian species Dictyotidium biscutulatum Kiryanov are present. (11): Belonechitina? sp. MPK 13550, sample 
GO44, Q35/3. (12, 15). Belonechitina? sp. Figure 6.15 showing detail of base. MPK 13551, sample GO44, T30/1. (13): ?Actinotodissus crassus Loeblich \& Tappan 1978. 2001,js,ksg,sa (5). (14, 17) Cryptospore tetrads? (14): MPK 13553, sample GO5, R12/2. (17): 79MH164 (21). (16). Desmochitina sp. 2001,js,ksg,9b. Bar on Fig. $3=5$ $\mu \mathrm{m}$ for Figure 6.15, $20 \mu \mathrm{m}$ for Figure 6.16, and $10 \mu \mathrm{m}$ for the rest. Specimens are held in the collections of the Palynological Laboratory, Geological Survey of Iran, except for those with MPK numbers, which are housed in the MPK (type and figured microfossils) collection of the British Geological Survey, Nottingham, U.K.

Fig. 7. Post-Cretaceous deformation in the middle part of the Neka Valley. (Sites NEKA4 and NEKA5). Cretaceous rocks cover folded marly limestones of the Qezel Qaleh Formation (Carboniferous). The Mesozoic unconformity is locally faulted (dashed great circle) along the hinge of the post-Cretaceous folds (NEKA 5a).

Fig. 8. Simplified geological map of the Talesh Mountains (western Alborz); modified from Geological Survey of Iran $(1975,1977)$ basing on our fieldwork. Traces of the cross-sections (fig.10) and location of the structural observations (fig.11) are shown in the map.

Fig. 9. Field photographs of the Eo-Cimmerian structures in the Talesh Mountains. (a): the Eo-Cimmerian unconformity along the Shah Rud valley just north of the village of Bellaché, right side of the valley. The Shemshak Formation basal conglomerates, containing pebbles of owgrade metamorphic and granitic rocks, unconformably cover deformed slates intruded by andesitic to gabbroic dikes. (b): mountain-scale exposure of the Eo-Cimmerian unconformity, about $1 \mathrm{~km} \mathrm{NE}$ of the summer village of Yeylagh, Siava Rud. Strongly deformed carbonatic meta-breccias are exposed below the unconformity (c). Brownish rocks on the right-side of the photo possibly represent lateritic soils developed along the unconformity.

Fig.10. Geological cross-sections across the Talesh Mountains showing EoCimmerian and Tertiary deformations; traces in figure 8. Shanderman Complex: Garnet-biotite micaschists (ms) and eclogites (ec). Masuleh-Shah Rud Unit: PermoCarboniferous limestones (PCca), Slate and Phyllite (PCph). Boghrov Dagh Unit: Silurian-?Early Devonian spilitic basalts (Silvs) with Silurian limestones with Nautiloids (ols), Carbonifeorous massive limestone with brachiopods (Cals) with ?Permian thin-bedded marly limestone (Pe), undifferentiated Upper Palaeozoic 
volcanics (Cavs). Sureh Khani Unit: Upper Devonian volcanoclastic deposits (vs) with thick andesitic lava flows (lf1) and bioclastic limestones (bls), uppermost Devonian to Carboniferous lava flows (lf2), Carboniferous coral and brachiopod massive limestone (cls), Carboniferous lava flows and breccias (lf3), Carboniferous marly limestone $(\mathrm{cm})$ and limestone (cl) with brachiopods, Uppermost Carboniferous?Permian, thin-bedded limestone with marlstone and shale. Pre-Jurassic Intrusives: serpentinized gabbro and cumulitic ultramafics (Gb-Um). Post-Eo-Cimmerian succession: Shemshak Formation (Sh) with conglomerates (Sh-cg) and volcanics (Shv), Middle-Upper Jurassic Shal Formation (Sl), Lower Cretaceous fine-grained limestone with ammonoids (Kln), Upper Cretaceous marly limestone (Kls) with sandstone (s), Upper Cretaceous tuffaceous volcanics, basalts and andesites with marlstone (m), Karaj Formation (Eocene): green acid tuffs and dacitic lavas (kd), andesitic tuffs (kds), andesitic lavas (kl) and andesitic tuffs with lava and volcaniclastics (kt), Upper Oligocene?-Pliocene? Red Formation: red marlstone with gypsum (a), red and grey conglomerates (b) and sandstones (c).

Fig. 11. Stereoplots comparing the Eo-Cimmerian structures with the ones related to the late Tertiary thrusting and folding. Note that the Eo-Cimmerian structures show a different trend (N-S) with respect to the younger folds (NW-SE). Location of the sites in fig.8.

Fig.12. Provenance analysis of Shemshak sandstones. The quartzolithic composition of Shemshak sandstones documents provenance from the Eo-Cimmerian Orogen (“Recycled Orogenic” Provenance, Dickinson 1985). Note significant difference between the Kandavan sandstones and the more quartzose and volcanic-free sandstones in the Shemshak type area (Assereto 1966a; 90\% confidence regions about the mean calculated after Weltje 2002). Lithic sandstones of the Masuleh area and slate-arenites to phyllite-arenites of the Ramedan (Neka Valley) area represent proximal deposits deposited by minor transverse rivers in the Eo-Cimmerian foreland basin.

Fig.13. Lithic fragments in the Shemshak sandstones. (a): quartzolithic sandstone containing both radiolarian chert (Ch), and felsic volcanic grains (Fv; Kandevan, IR4); (b): lithic sandstone rich in dolostone grains (Do; Masuleh, IR9); (c): lithic sandstone rich in shale/slate grains (IR8; Masuleh, TZ2; Shah Rud); (d): lithic 
sandstone rich in phyllite grains (Ph; Ramedan, GO31). Scale bar= 250 microns. All photos with cross polars.

Fig. 14. Tentative sketch of the relationships between the extensional structures formed in the Eo-Cimmerian foreland the Eo-Cimmerian belt; modified from Zanchi et al. (2006).

Fig.15. Summary of the available data concerning the evolution of the Eo-Cimmerian orogen in the Alborz and of the Palaeotethys suture zone, based on our unpublished data and on Alavi (1991), Alavi et al. (1997), Ruttner (1993); Geological Survey of Iran (1986, 1993, 1996), Seyed-Emami (2003); Fursich et al. (2005); Ghasemi-Nejad et al., (2004), Zanchi et al. (2006). Dark-grey indicates compression, light-grey extension.

Table 1. Detrital modes of Shemshak sandstones. In each of ten coarse-siltstone to mediumgrained-sandstone samples, 400 to 450 points were counted according to the Gazzi-Dickinson method (Ingersoll et al. 1984). A detailed classification scheme allowed us to collect quantitative information on metamorphic rank of rock fragments (MI index; Garzanti \& Vezzoli 2003). Thin sections were stained with alizarine red to distinguish calcite from dolomite. Mean grain size of studied samples was determined by ranking and direct measurement in thin section. All compositional parameters are defined in Garzanti et al. (2006). Coordinates are from GPS (WGS84). 


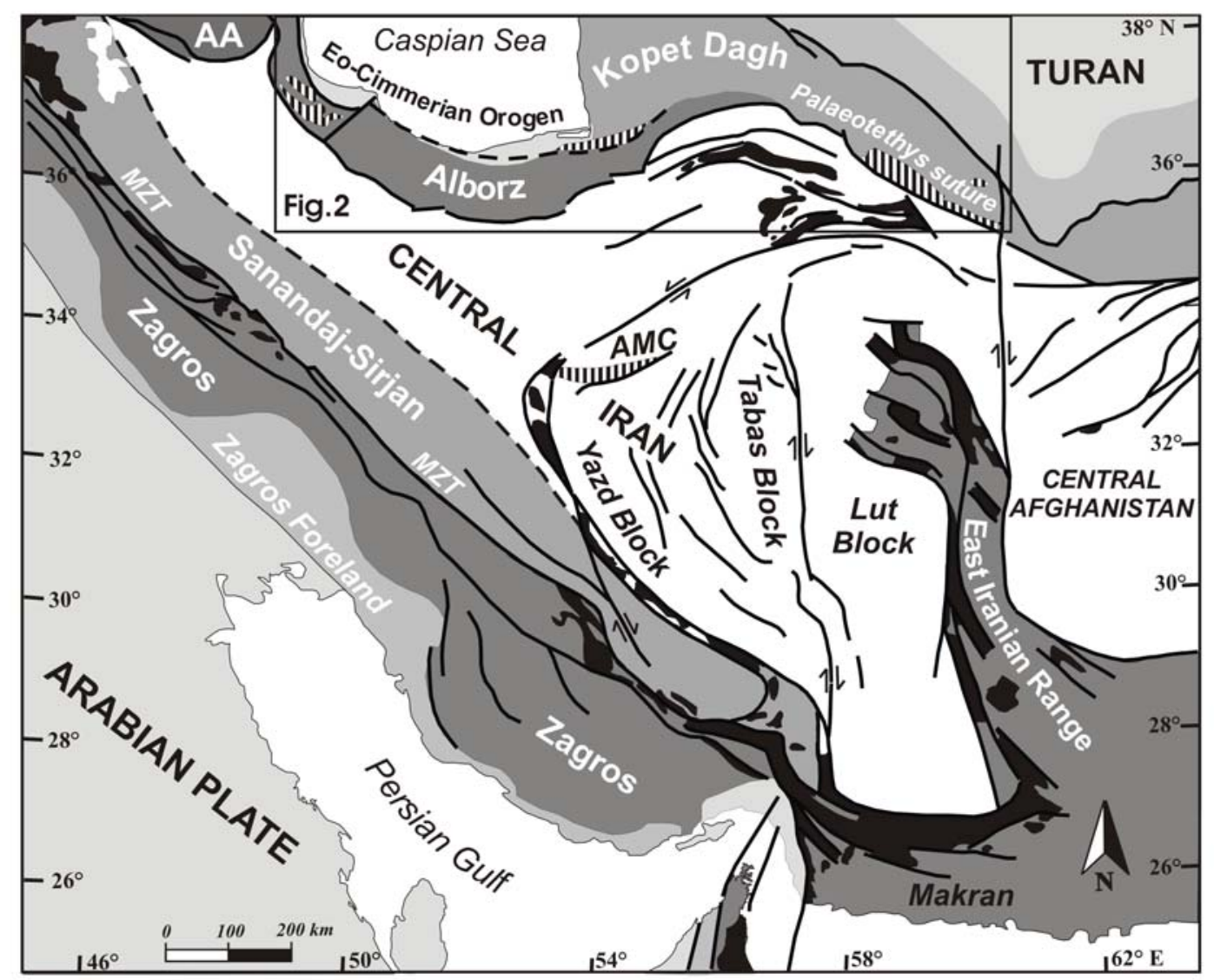

Fig.1 


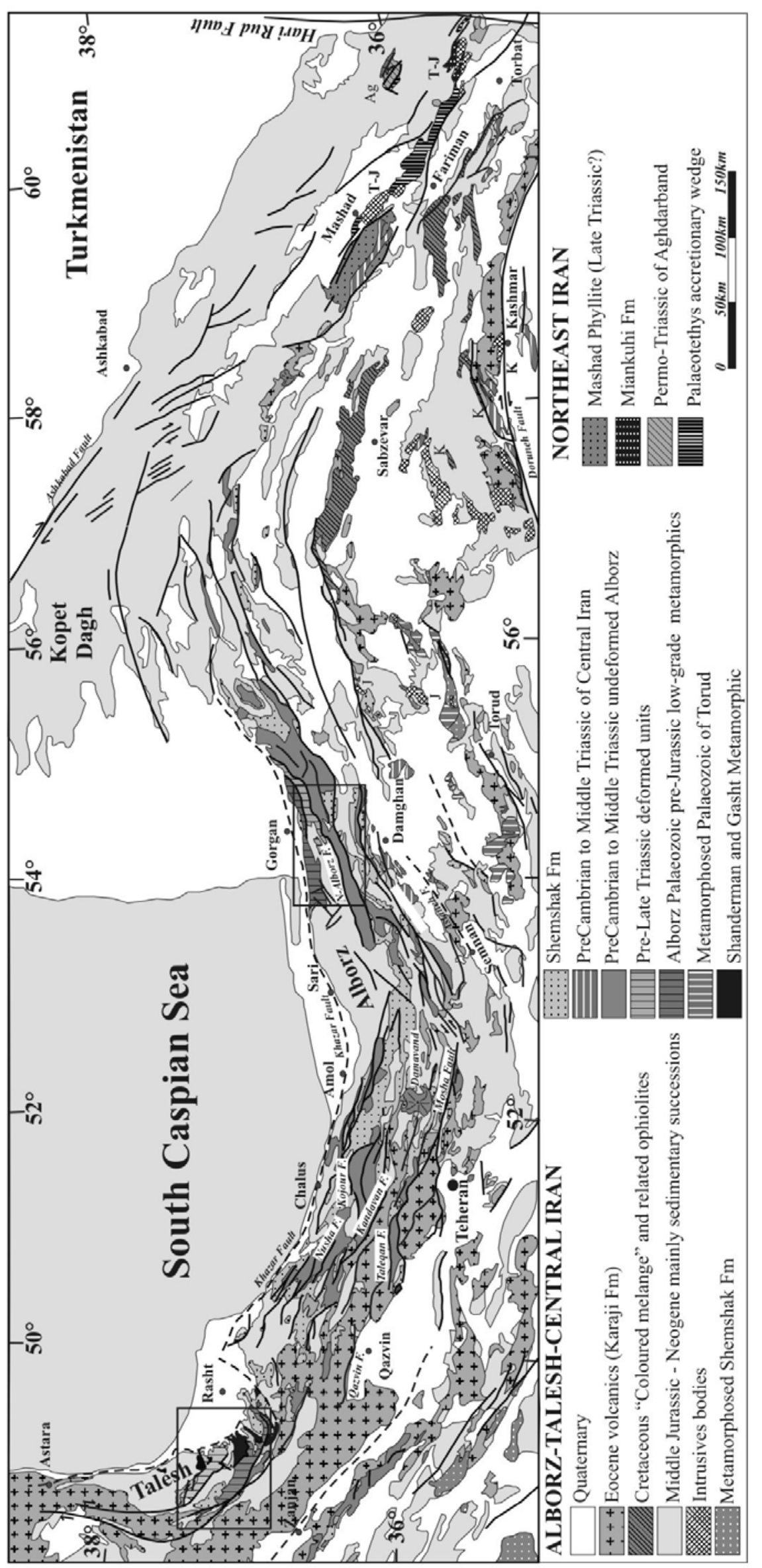

Fig.2 


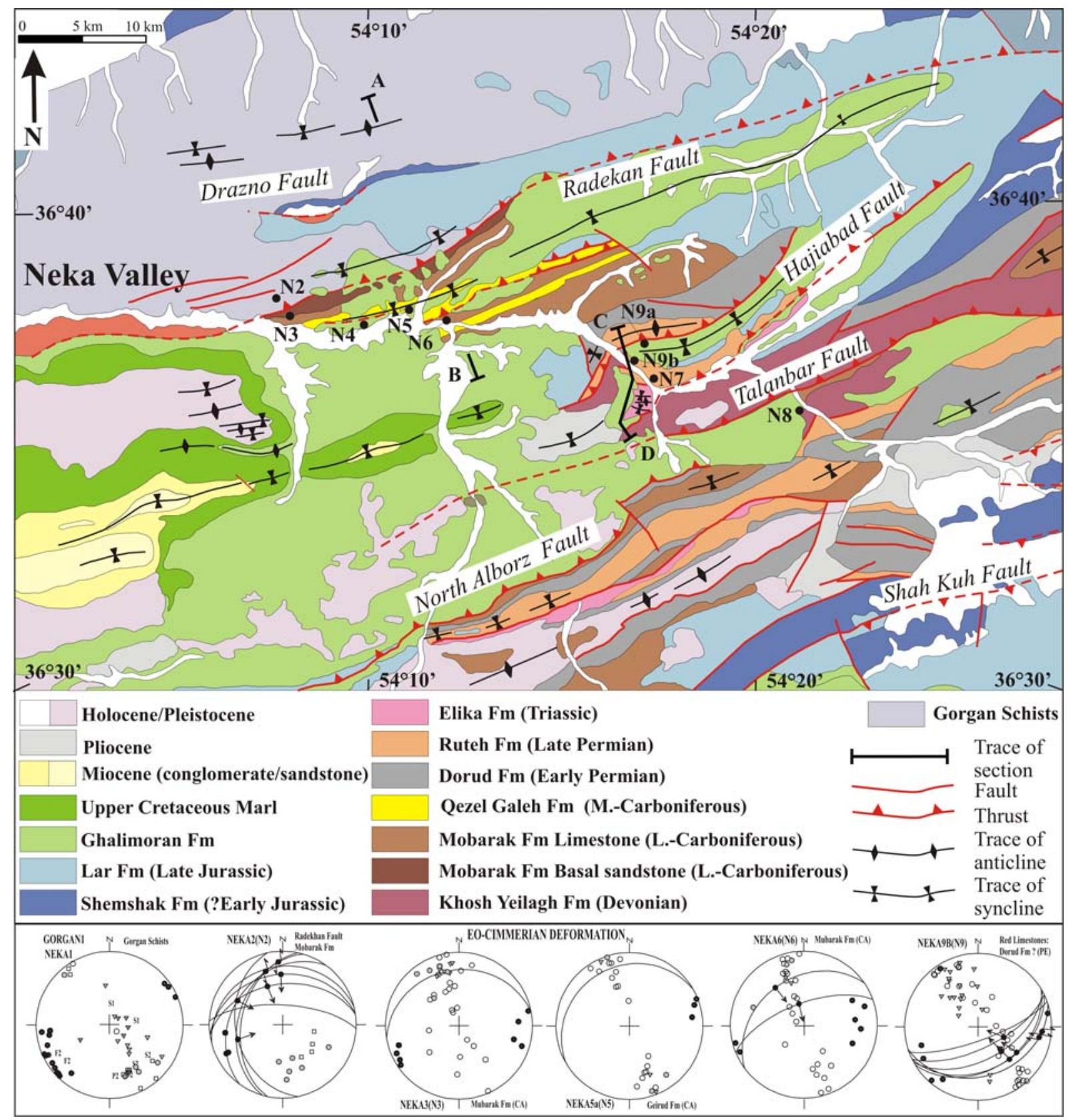

Fig.3 

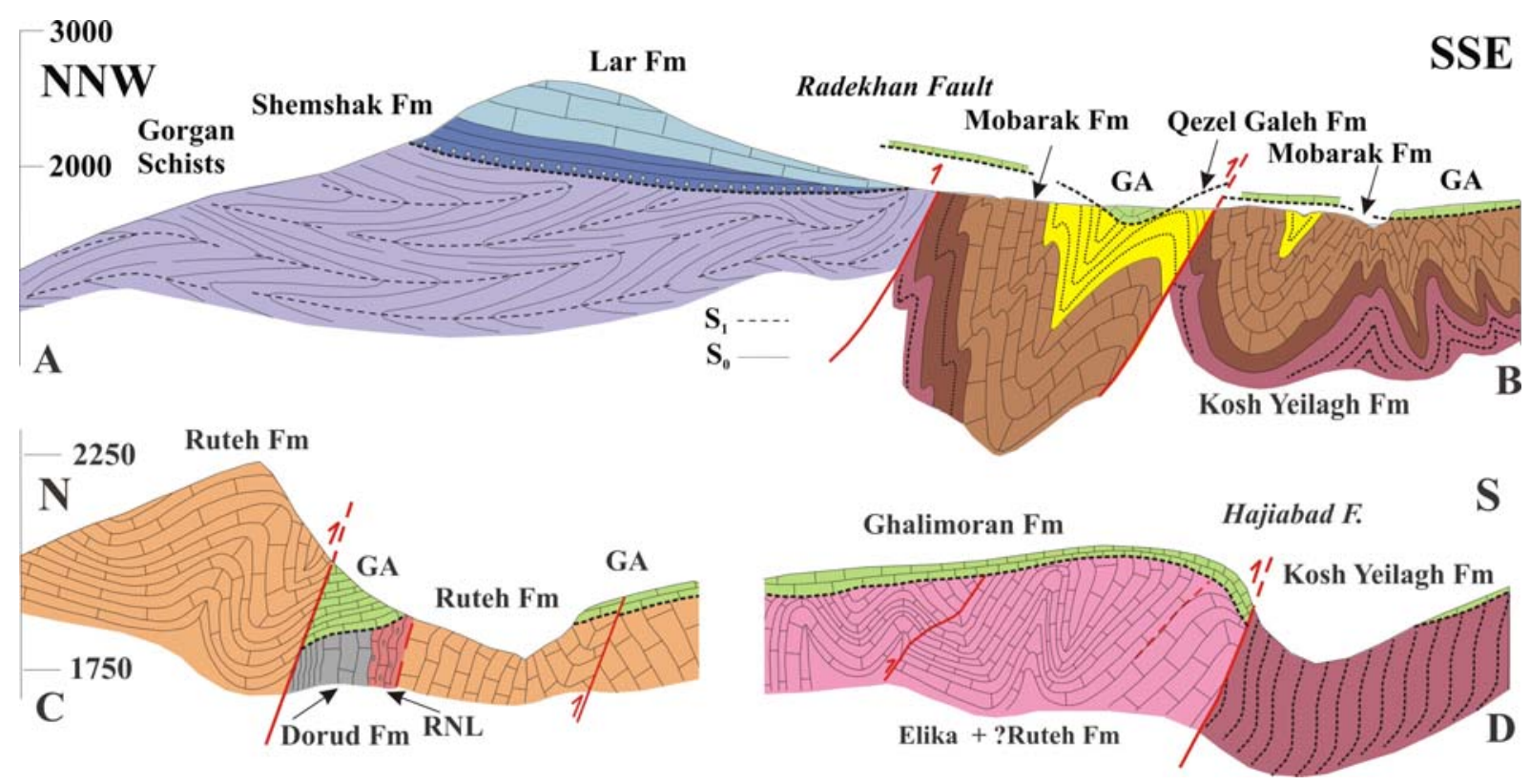

Fig.4 

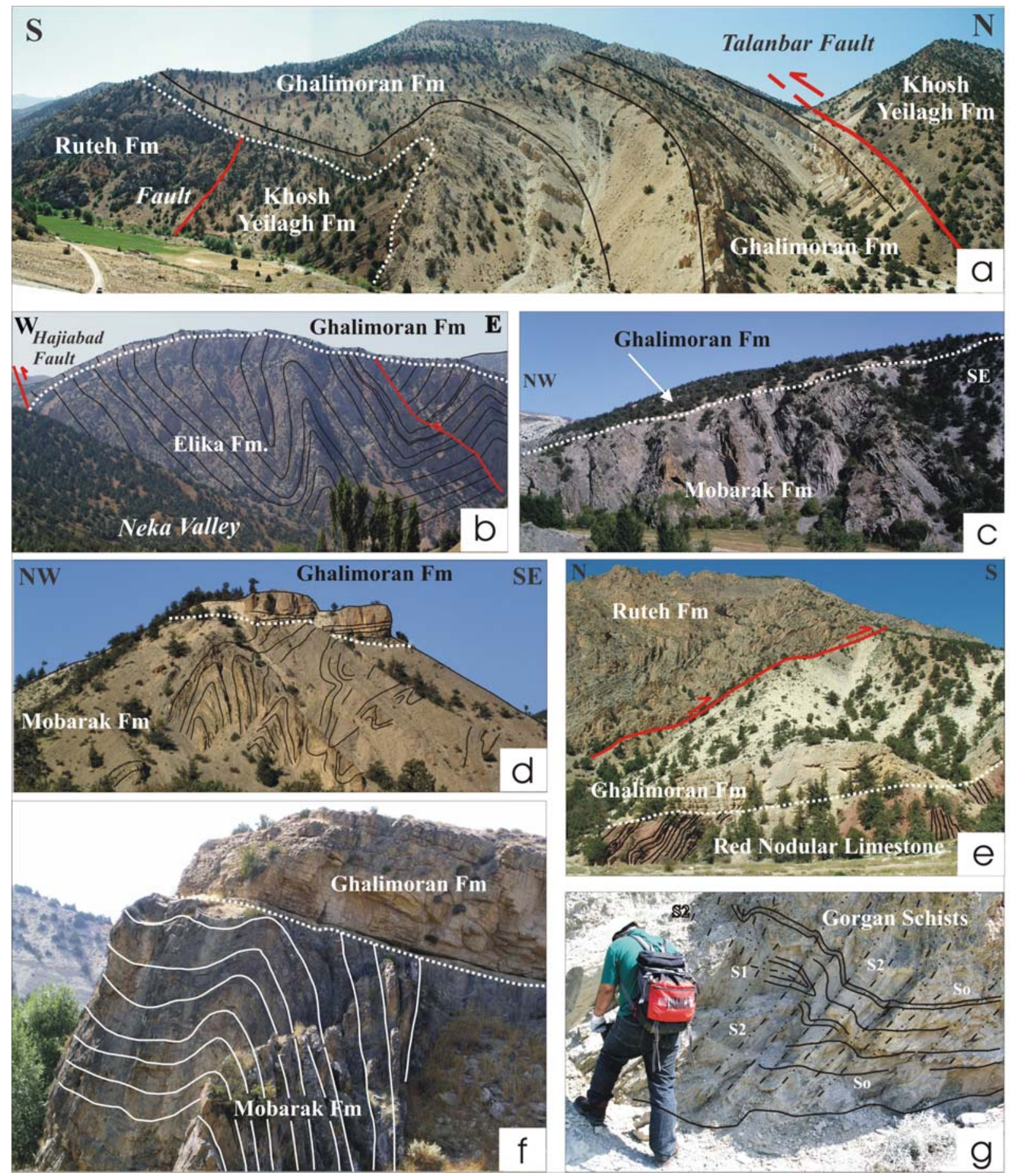

Fig.5 

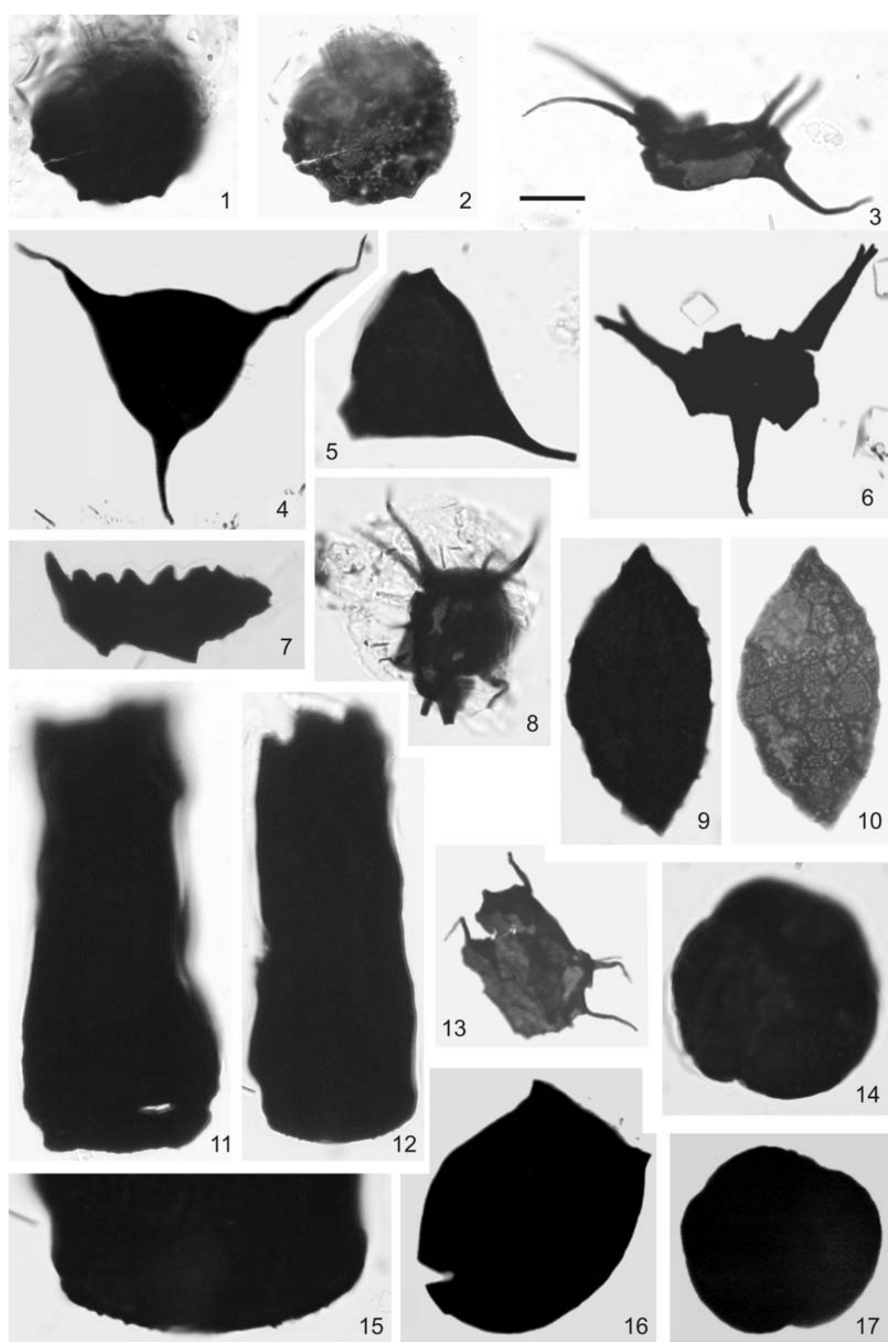

Fig. 6 

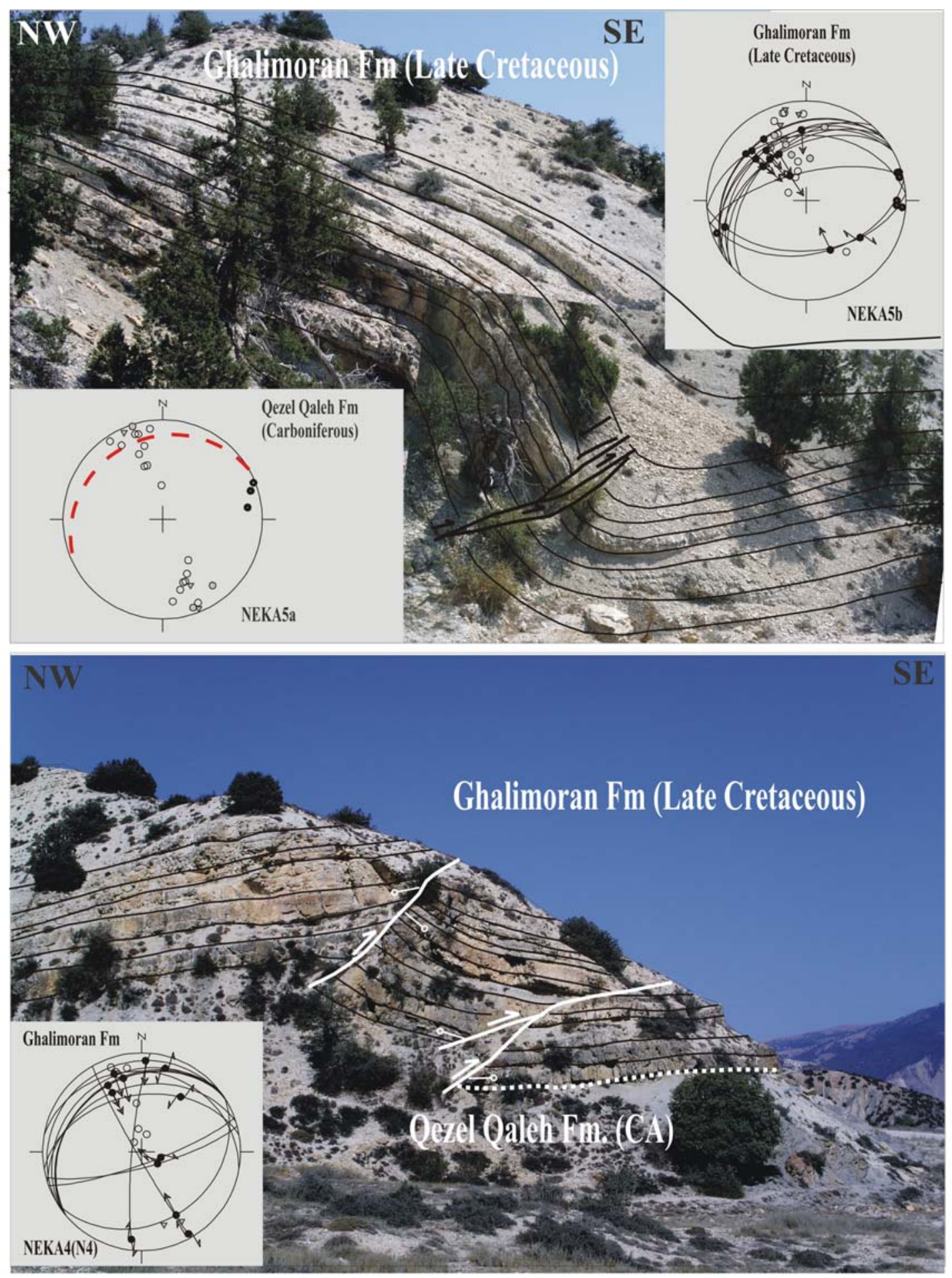

Fig.7 


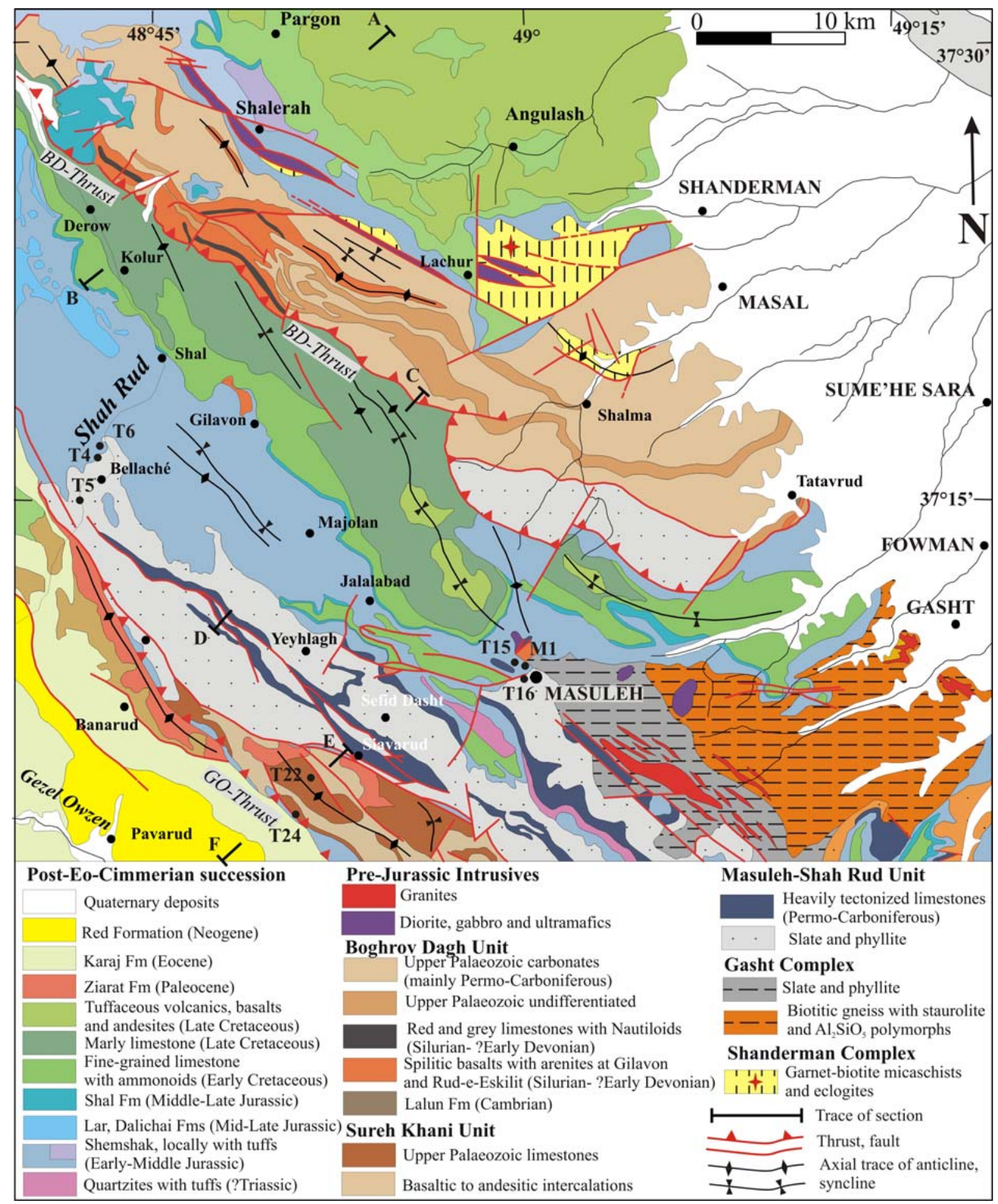

\section{Fig.8}



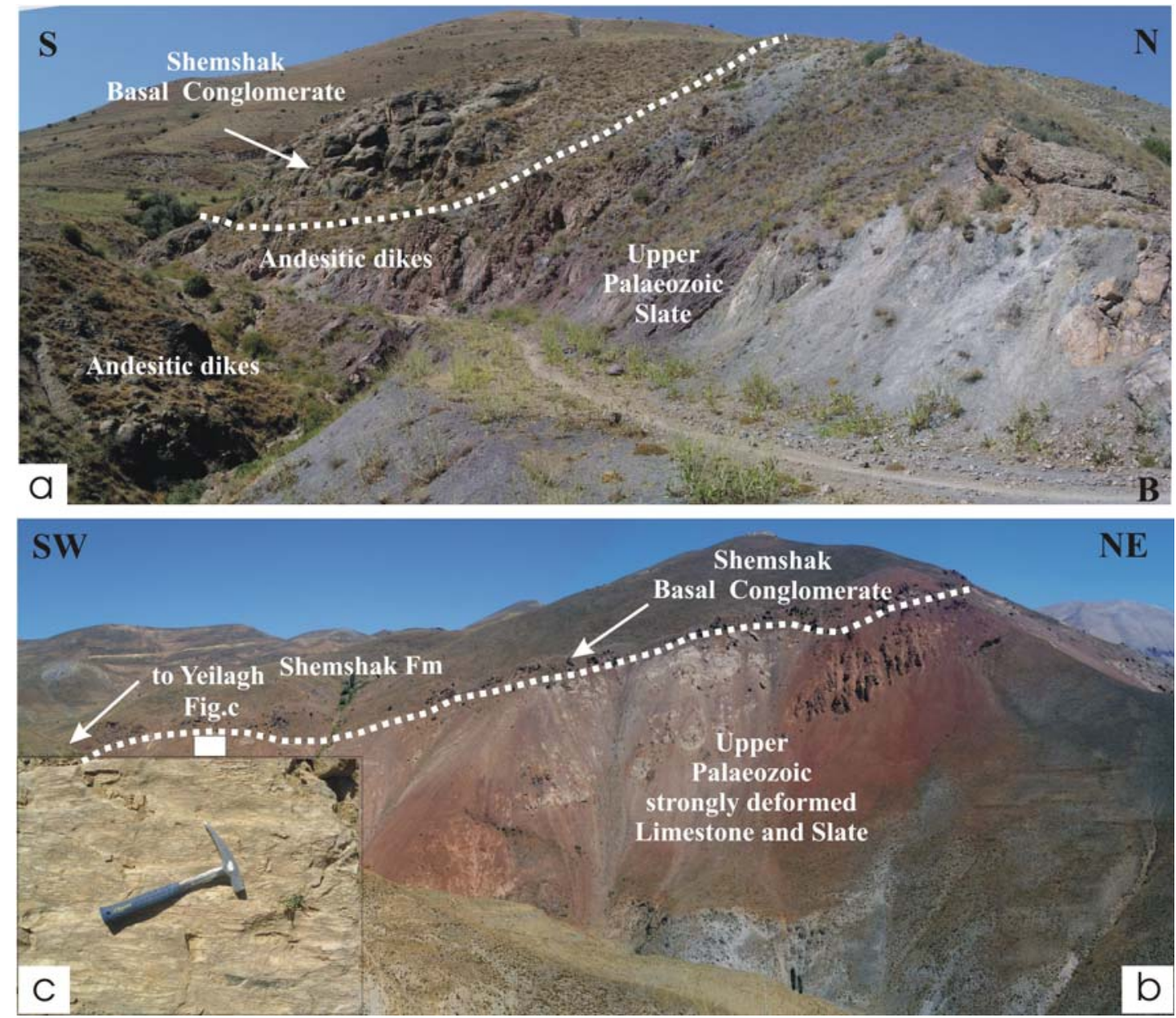

Fig.9

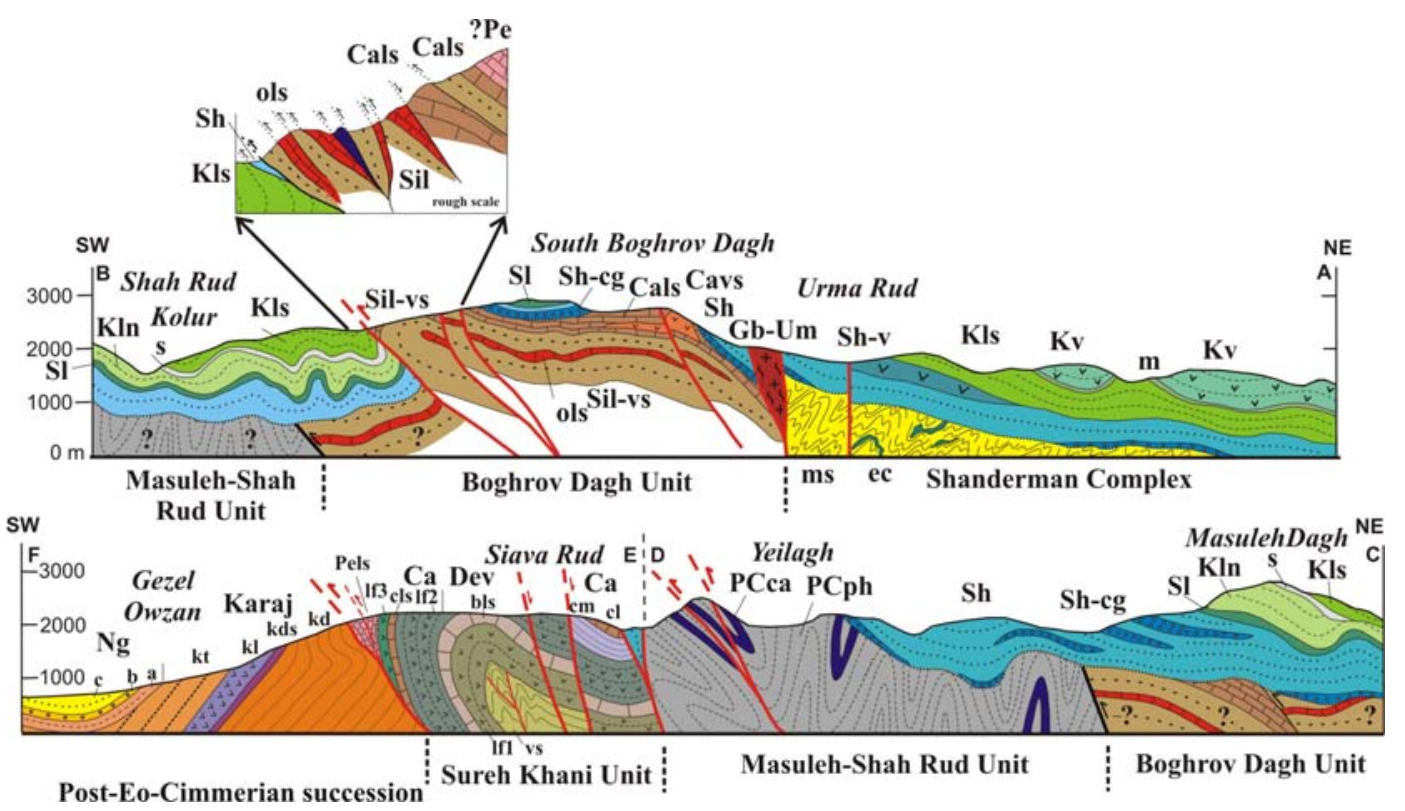

Fig. 10 


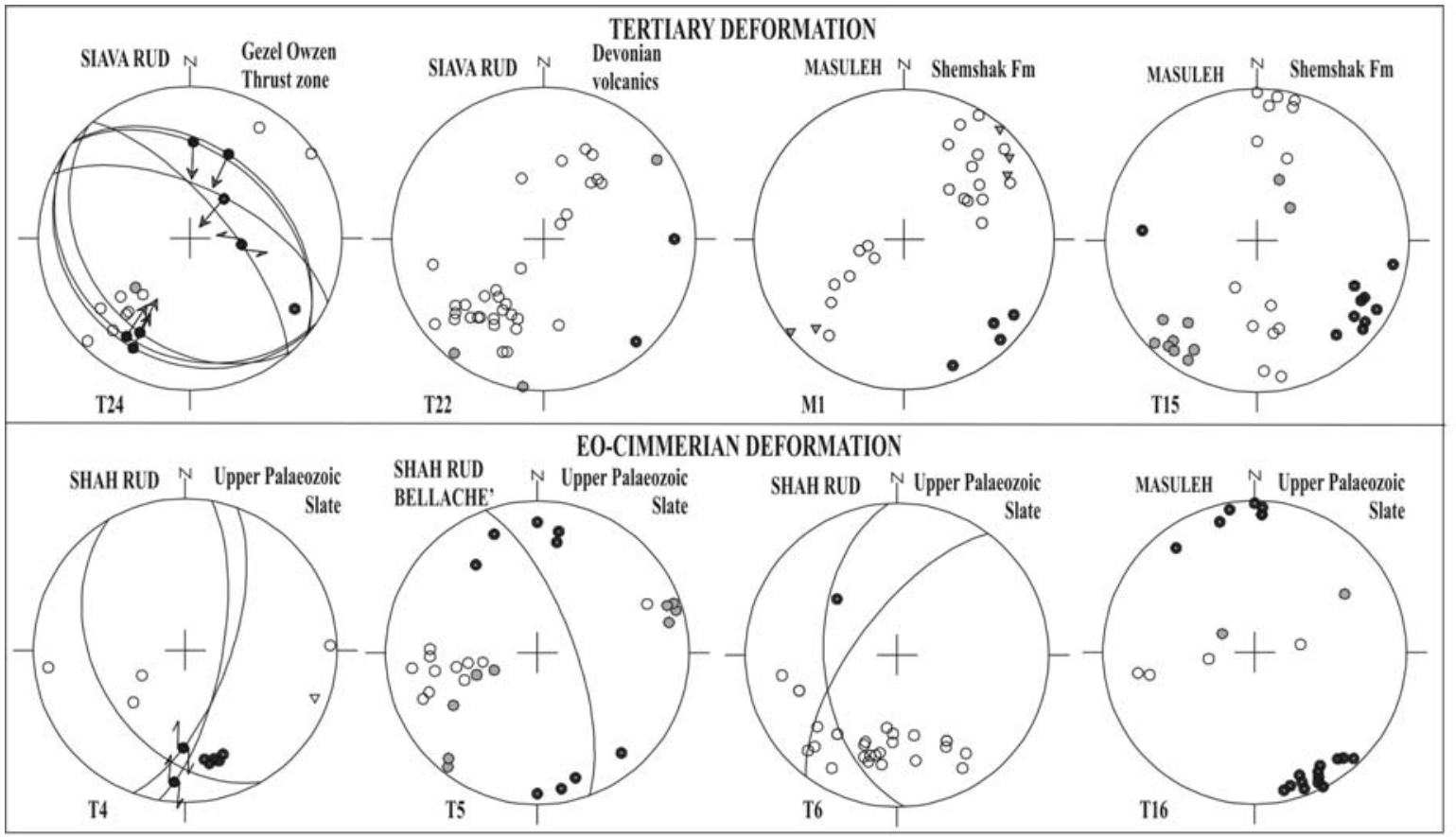

Fig.11 


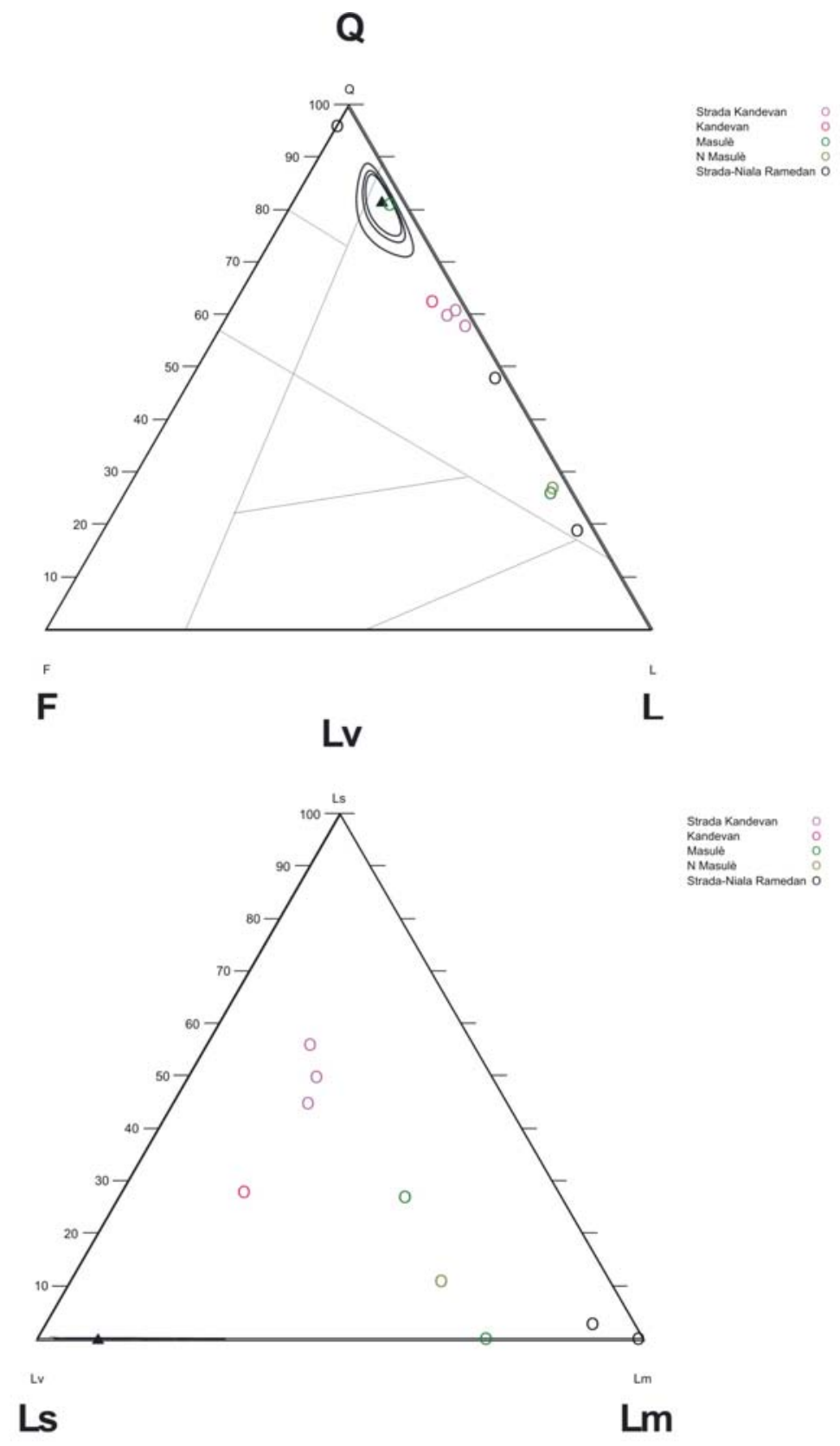

Fig.12

$4 \theta_{\wedge}$ 

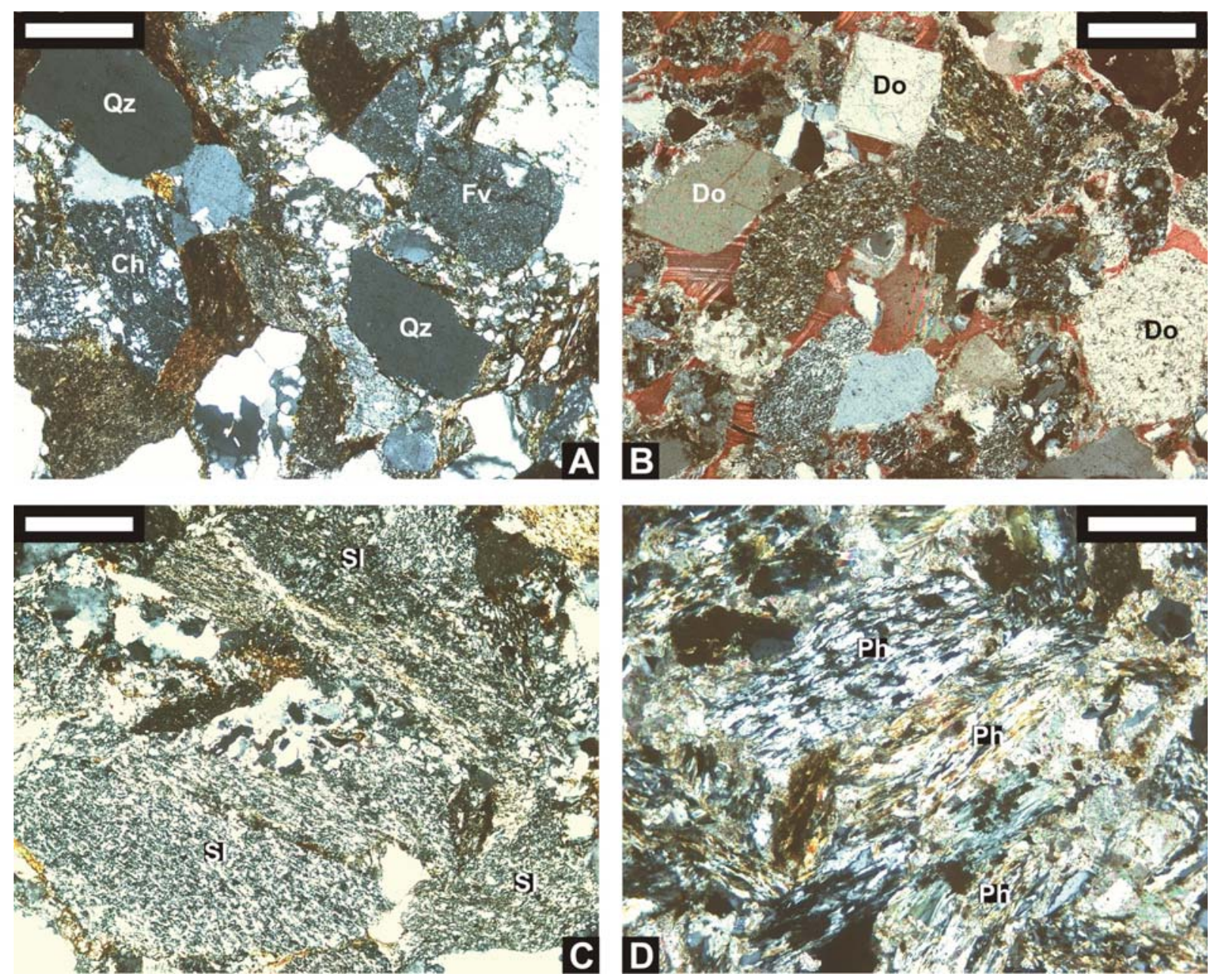

Fig.13

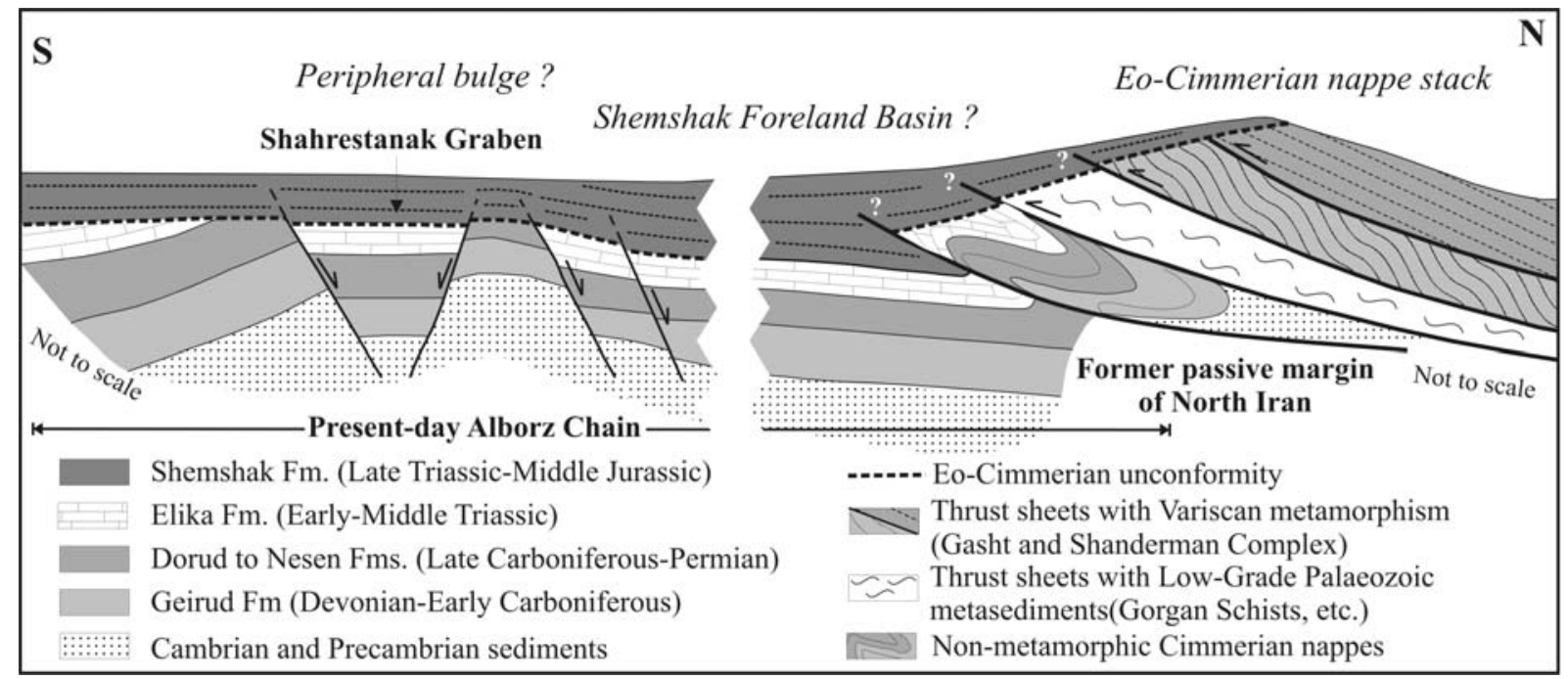

Fig.14 


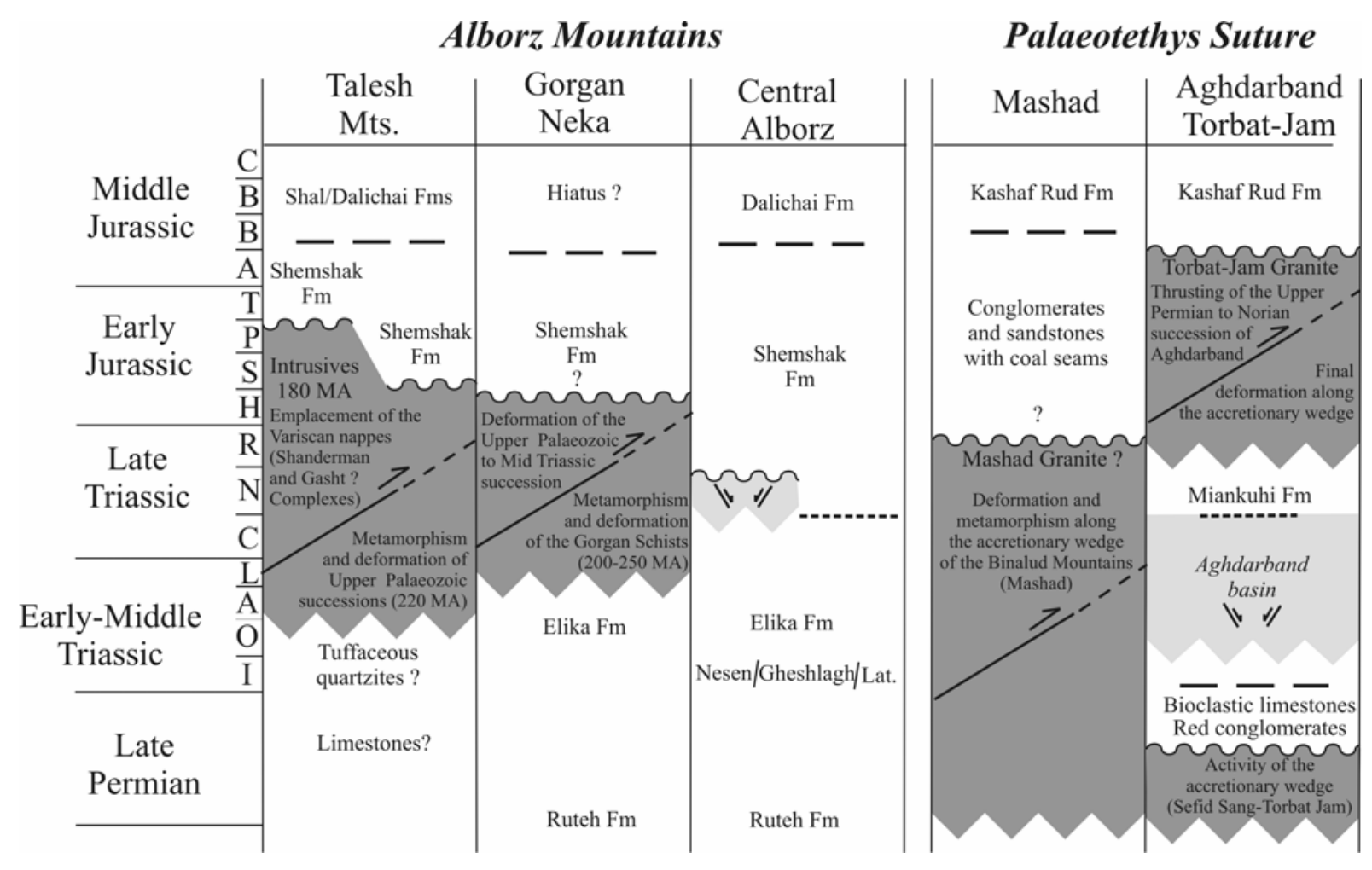

Fig.15 


\begin{tabular}{|c|c|c|c|c|c|c|c|c|c|c|c|c|c|c|c|c|c|c|c|c|c|c|c|c|c|c|c|}
\hline $\begin{array}{l}\text { SHEMSHAK } \\
\text { FORMATION }\end{array}$ & $\begin{array}{l}\text { क्ष } \\
\text { हू } \\
\text { हू }\end{array}$ & 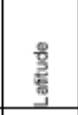 & 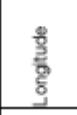 & Provenance & 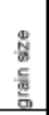 & Q & KF & $\mathbf{P}$ & Lvf & Lvm & Lec & Led & Lp & Lch & Lms & Lmv & Lmf & $L \mathrm{mb}$ & Luc & Lus & $\mathrm{Mu}$ & $\mathrm{Bi}$ & $\begin{array}{l}\frac{8}{8} \\
\frac{8}{2} \\
\frac{2}{2}\end{array}$ & 촏 & $\frac{\overline{6}}{8}$ & $\Sigma$ & 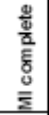 \\
\hline Kandavan & IRA & $36^{*} 1144$ & $51^{\circ} 1910^{\circ}$ & Recycled w. voicanic & 270 & 61 & 0 & 2 & 9 & 1 & 0 & 0 & 18 & 2 & 7 & 0 & 0 & 0 & 0 & 0 & 0 & 0 & 0 & 0 & 100,0 & 139 & 35 \\
\hline ndavan & $\mathbb{R} 5$ & $36^{\circ} 11^{\prime}+4^{\prime \prime}$ & $51^{\circ} 191 \sigma^{\circ}$ & Recycled w. voicanic & 220 & 58 & 1 & 1 & 10 & 2 & 0 & 0 & 17 & 3 & 6 & 0 & 2 & 0 & 0 & 0 & 0 & 0 & 0 & 0 & 100,0 & 161 & 48 \\
\hline Kandavan & $\mathbb{R} 6$ & $36^{\circ} 114^{\prime}$ & $511^{\circ} 1910^{\circ}$ & Recycled w. voicanic & 220 & 60 & 1 & 3 & 9 & 3 & 0 & 0 & 15 & 1 & 7 & 0 & 1 & 0 & 0 & 0 & 0 & 0 & 0 & 0 & 100,0 & 153 & 47 \\
\hline Kandavan & IR7 & $36^{\circ} 1037$ & $51 \% 1837$ & Recycled w. voicanic & 220 & 63 & 2 & 4 & 15 & 1 & 0 & 0 & $\theta$ & 0 & 3 & 0 & 4 & 0 & 0 & 0 & 0 & 0 & 0 & 0 & 100,0 & 239 & 68 \\
\hline sule & IRB & $37^{\circ} 0923^{\prime \prime}$ & $48^{*} 5929^{*}$ & Qtz. recycled & 110 & 79 & 0 & 2 & 3 & 1 & 0 & 0 & 0 & 0 & 10 & 0 & 2 & 0 & 0 & 0 & 2 & 0 & 0 & 0 & 100,0 & 223 & 158 \\
\hline Masule & IR9 & $37^{\circ} 09_{23}$ & $48^{*} 5929^{\circ}$ & Slate-volotcaro & 270 & 27 & 1 & 3 & 12 & 6 & 7 & 11 & 0 & 1 & 29 & 1 & 4 & 0 & 0 & 0 & 0 & 0 & 0 & 0 & 100,0 & 192 & 126 \\
\hline Shan Fud & TZ2 & $37: 1721^{*}$ & $48^{\circ} 42^{4-5}$ & Slate+volcarics & 300 & 27 & 1 & 2 & 12 & 8 & 0 & 0 & 7 & 1 & 36 & 4 & 2 & 0 & 0 & 1 & 0 & 0 & 0 & 0 & 100,0 & 162 & 111 \\
\hline Nlala-Ramedan & GO32 & $36^{*} 3653$ & $53 \times 4724$ & Pryllte arenite & 150 & 46 & 1 & 1 & 2 & 2 & 1 & 0 & 0 & 0 & 12 & 0 & 31 & 0 & 0 & 0 & 4 & 1 & 0 & 0 & 100,0 & 320 & 300 \\
\hline & GO31 & $36^{*} 3653$ & $53 \% 4724$ & slate a & 140 & 18 & 0 & 3 & 1 & 0 & 0 & 0 & 0 & 0 & 55 & 2 & 14 & 0 & 0 & 0 & 3 & 4 & 0 & 0 & 100,0 & 227 & 221 \\
\hline Nala-Ramedan & GO29 & $36^{\circ} 3653$ & $53 \% 4724$ & atz. recycled & 50 & 85 & 1 & 3 & 0 & 0 & 0 & 0 & 0 & 0 & 0 & 0 & 0 & 0 & 0 & 0 & 0 & 0 & 0 & 0 & 100,0 & n.d. & n.d. \\
\hline
\end{tabular}

Table 1 